\title{
Rapid Signaling of Estrogen in Hypothalamic Neurons Involves a Novel G-Protein-Coupled Estrogen Receptor that Activates Protein Kinase C
}

\author{
Jian Qiu, ${ }^{1}$ Martha A. Bosch, ${ }^{1}$ Sandra C. Tobias, ${ }^{2}$ David K. Grandy, ${ }^{1}$ Thomas S. Scanlan, ${ }^{2}$ Oline K. Rønnekleiv, ${ }^{1}$ and \\ Martin J. Kelly ${ }^{1}$ \\ ${ }^{1}$ Department of Physiology and Pharmacology, Oregon Health and Science University, Portland, Oregon 97239, and 2Department of Pharmaceutical \\ Chemistry, University of California, San Francisco, San Francisco, California 94143
}

\begin{abstract}
Classically, $17 \beta$-estradiol $\left(E_{2}\right)$ is thought to control homeostatic functions such as reproduction, stress responses, feeding, sleep cycles, temperature regulation, and motivated behaviors through transcriptional events. Although it is increasingly evident that $\mathrm{E}_{2}$ can also rapidly activate kinase pathways to have multiple downstream actions in CNS neurons, the receptor(s) and the signal transduction pathways involved have not been identified. We discovered that $\mathrm{E}_{2}$ can alter $\mu$-opioid and GABA neurotransmission rapidly through nontranscriptional events in hypothalamic GABA, proopiomelanocortin (POMC), and dopamine neurons. Therefore, we examined the effects of $\mathrm{E}_{2}$ in these neurons using whole-cell recording techniques in ovariectomized female guinea pigs. $\mathrm{E}_{2}$ reduced rapidly the potency of the $\mathrm{GABA}_{\mathrm{B}}$ receptor agonist baclofen to activate G-protein-coupled, inwardly rectifying $\mathrm{K}^{+}$channels in hypothalamic neurons. These effects were mimicked by the membrane impermeant $\mathrm{E}_{2}-\mathrm{BSA}$ and selective estrogen receptor modulators, including a new diphenylacrylamide compound, STX, that does not bind to intracellular estrogen receptors $\alpha$ or $\beta$, suggesting that $\mathrm{E}_{2}$ acts through a unique membrane receptor. We characterized the coupling of this estrogen receptor to a $\mathrm{G} \alpha$-mediated activation of phospholipase $\mathrm{C}$, leading to the upregulation of protein kinase $\mathrm{C} \delta$ and protein kinase $\mathrm{A}$ activity in these neurons. Moreover, using single-cell reverse transcriptionPCR, we identified the critical transcripts, PKC $\delta$ and its downstream target adenylyl cyclase VII, for rapid, novel signaling of $E_{2}$ in GABA, POMC, and dopamine neurons. Therefore, this unique $\mathrm{G}_{\mathrm{q}}$-coupled estrogen receptor may be involved in rapid signaling in hypothalamic neurons that are critical for normal homeostatic functions.
\end{abstract}

Key words: $\mathrm{GABA}_{\mathrm{B}}$ receptor; GIRK; dopamine; GAD; POMC; SERMs

\section{Introduction}

It is becoming increasingly evident that the gonadal steroid hormone $17 \beta$-estradiol $\left(\mathrm{E}_{2}\right)$ imparts a multifaceted influence over synaptic transmission in the mammalian CNS. Not only can estrogen alter synaptic responses via estrogen response elementdriven target gene transcription, but $\mathrm{E}_{2}$ can also rapidly modulate cell-to-cell communication via membrane-initiated, rapid signaling events (for review, see Kelly and Wagner, 1999). These synaptic alterations are brought about via changes in the cellular responsiveness to the activation of various receptor systems (both G-protein-coupled and ionotropic) to their respective first messengers. $E_{2}$ can alter the linkage of G-protein-coupled receptor (GPCR) systems such as opioid (both $\mu$ and $\kappa$ ), GABA $_{\mathrm{B}}$, and dopamine $D_{2}$ receptors to their respective effector systems (Demotes-Mainard et al., 1990; Kelly et al., 1992; Takano et al.,

Received June 13, 2003; revised Aug. 1, 2003; accepted Aug. 22, 2003.

This research was supported by United States Public Health Service Grants NS 35944 (Office of Research on Women's Health), NS 38809, DA 05158, DA 10703, and DK57574. We thank Drs. D. James Surmeier and Tania Tkatch for their help and advice in establishing the single-cell RT-PCR technique in our laboratory. We also recognize Barry R. Naylor and Rebecka D. Amodei for their expert technical contribution.

Correspondence should be addressed to Dr. Martin J. Kelly, Department of Physiology and Pharmacology, L334, Oregon Health and Science University, Portland, OR 97239-3098. E-mail: kellym@ohsu.edu.

Copyright $\odot 2003$ Society for Neuroscience $\quad$ 0270-6474/03/239529-12\$15.00/0
1994; Wagner et al., 1994; Lagrange et al., 1996). In addition, $\mathrm{E}_{2}$ can act as an allosteric modulator of ionotropic receptors, such as 5- $\mathrm{HT}_{3}$ and nicotinic receptors (Wetzel et al., 1998; Paradiso et al., 2001), or by direct binding to subunits of ion channels, such as the $\beta_{1}$ subunit of the maxi- $\mathrm{K}^{+}$channel (Valverde et al., 1999). These fundamentally distinct signaling pathways give rise to a coordinated regulation by estrogen of complex physiological processes to maintain homeostasis in the mammal (McEwen, 2001).

The quintessential role of estrogen in the CNS is to transmit feedback information to gonadotropin-releasing hormone $(\mathrm{GnRH})$ neurons that control the female reproductive cycle. Estrogen can alter GnRH neuronal activity directly (Kelly et al., 1984; Lagrange et al., 1995) or it can act upstream to alter synaptic input to GnRH neurons (Watson et al., 1992; Herbison et al., 1995, 2001; Sullivan et al., 1995; Simonian et al., 1999). Two of the major presynaptic target neurons of estrogen are the proopiomelanocortin (POMC) and GABA neurons, both of which provide a prominent synaptic input onto $\mathrm{GnRH}$ neurons (Morrell et al., 1985; Leranth et al., 1992; Herbison, 1997). Both opioid peptides and GABA inhibit GnRH output (Ferin et al., 1984; Mitsushima et al., 1996) and luteinizing hormone release (Ferin et al., 1984; Akema et al., 1990; Seltzer and Donoso, 1992; Jarry et al., 
1995) from the anterior pituitary. Another target of the actions of estrogen is the arcuate dopamine (tuberoinfundibular) neurons that are located in the arcuate nucleus and project to the median eminence, in which they release dopamine into the portal circulation, which directly inhibits prolactin secretion from anterior pituitary lactotrophs (Neill, 1980; Björklund and Lindvall, 1984; Hökfelt et al., 1984).

$\mu$-Opioid and $\mathrm{GABA}_{\mathrm{B}}$ receptors are linked to the same population of $\mathrm{G}$-protein-coupled inwardly rectifying $\mathrm{K}^{+}$(GIRK) channels in hypothalamic POMC, dopamine, and GABA neurons (Loose et al., 1990, 1991; Wagner et al., 2000). Activation of either $\mu$-opioid or $\mathrm{GABA}_{\mathrm{B}}$ receptors elicits an outward $\mathrm{K}^{+}$current that robustly hyperpolarizes hypothalamic neurons. However, maximum activation of either receptor occludes the response of the other receptor (Loose et al., 1991; Wagner et al., 1999, 2001). Interestingly, short-term exposure to estrogen reduces the potency of both $\mu$-opioid and $\mathrm{GABA}_{\mathrm{B}}$ receptor agonists to activate GIRK channels in hypothalamic neurons (Lagrange et al., 1994, 1996, 1997). The underlying mechanism of this estrogen-induced decrease in the responsiveness of hypothalamic neurons to the $\mu$-opioid and $\mathrm{GABA}_{\mathrm{B}}$ agonists is not known. Recent experiments have shown that selective protein kinase $A$ (PKA) inhibitors can block the effects of estrogen, and PKA activators mimic the effects of estrogen on the coupling of $\mu$-opioid receptor to GIRK (Lagrange et al., 1997). Therefore, in the present study, we characterized the estrogen-mediated rapid signaling pathway in hypothalamic neurons by using novel estrogen receptor (ER) ligands. In addition, by using specific protein kinase inhibitors and single-cell reverse transcription (scRT)-PCR, we found that this novel estrogen receptor is coupled to $\mathrm{G} \alpha_{\mathrm{q}}$ and activates a phospholipase $\mathrm{C}$ (PLC)-protein kinase $\mathrm{C} \delta$-protein kinase A pathway. We conclude that stimulation of this pathway by binding of natural estrogen hormone and certain selective estrogen receptor modulators (SERMs) to the novel $\mathrm{G}_{\mathrm{q}}$-coupled estrogen receptor mediates the rapid steroid response in hypothalamic neurons.

\section{Materials and Methods}

Animals and treatments. All animal procedures described in this study are in accordance with institutional guidelines based on National Institutes of Health standards. Female Topeka guinea pigs (400-600 gm), bred in our institutional breeding facility, and female multicolor guinea pigs (400-500 gm; Elm Hill Breeding Labs, Chelmsford, MA) were used in these experiments. The guinea pigs were maintained under constant temperature $\left(26^{\circ} \mathrm{C}\right)$ and light (on between 6:30 A.M. and 8:30 P.M.). Animals were housed individually, with food and water provided ad libitum. They were ovariectomized under ketamine-xylazine anesthesia (33 and $6 \mathrm{mg} / \mathrm{kg}$, respectively, s.c.) 5-7 d before experimentation, and they were given sesame oil vehicle $(0.1 \mathrm{ml}$, s.c.) $24 \mathrm{hr}$ before experimentation. Serum estrogen concentrations were determined by radioimmunoassay (Wagner et al., 2001) from trunk blood collected on the day of experimentation and were $<10 \mathrm{pg} / \mathrm{ml}$. An additional group of animals $(n=6)$ were ovariectomized and, after 1 week, were injected with oil vehicle, estradiol benzoate ( $25 \mu \mathrm{g}$ in oil), or STX ( $25 \mu \mathrm{g}$ in oil) $24 \mathrm{hr}$ before they were killed. The uteri were collected, weighed, and fixed in $4 \%$ paraformaldehyde for later histological analysis, which is not being reported in this paper.

Wild-type C57BL/6 mice in these studies were obtained from The Jackson Laboratory (Bar Harbor, ME). All animals were maintained under controlled temperature $\left(25^{\circ} \mathrm{C}\right)$ and photoperiod conditions $(14 / 10$ $\mathrm{hr}$ light/dark cycle; lights on between 7:00 A.M. and 9:00 P.M.) with food and water ad libitum. Adult mice were ovariectomized under isoflurane anesthesia and allowed to recover for 1 week. At this time, the animals were injected daily for $2 \mathrm{~d}$ with oil vehicle, estradiol benzoate $(1 \mu \mathrm{g})$, or STX $(2$ or $5 \mu \mathrm{g})$ and anesthetized and killed by decapitation after $24 \mathrm{hr}$.
The uteri were collected, weighed, and fixed in $4 \%$ paraformaldehyde for later histological analysis, which is not being reported in this paper.

Drugs. All drugs were purchased from Calbiochem (La Jolla, CA) unless otherwise specified. Tetrodotoxin (TTX) (Alomone Labs, Jerusalem, Israel) was dissolved in Milli- $\mathrm{Q}_{2} \mathrm{O}$ and further diluted with $0.1 \%$ acetic acid (final concentration, $1 \mathrm{~mm}$ ), $\mathrm{pH} 4-5.17 \beta$-Estradiol was purchased from Steraloids (Wilton, $\mathrm{NH}$ ), recrystallized to ensure purity, and dissolved in $100 \%$ ethanol to a stock concentration of $1 \mathrm{mM} .17 \alpha$-Estradiol (17 $\alpha$ - $\mathrm{E}_{2} ; 1 \mathrm{~mm}$; Steraloids), anti-estrogen (ICI 182,780; $10 \mathrm{~mm}$; Tocris Cookson, Ballwin, $\mathrm{MO}$ ), and the selective estrogen receptor modulators 4-OH-tamoxifen (10 mm; Steraloids), raloxifene (10 mM; Eli Lilly and Company, Indianapolis, IN), and STX (10 mM) were also dissolved in $100 \%$ ethanol. $17 \beta$-Estradiol 17-hemisuccinate: BSA ( $\left.\mathrm{E}_{2}-\mathrm{BSA}\right)(1 \mathrm{~mm}$; Steraloids) was dissolved in $\mathrm{H}_{2} \mathrm{O}$. The protein kinase A inhibitor $\mathrm{H}-89$ dihydrochloride $(10 \mathrm{mM})$, the protein kinase A activator forskolin (50 $\mathrm{mM}$ ), the protein kinase $\mathrm{C}$ inhibitors bisindolylmaleimide I hydrochloride (BIS) $(100 \mu \mathrm{M})$, Gö6976 (2 mM), and rottlerin (10 mM), the phospholipase C inhibitor U73122 (20 mM), the less active analog U73343 (20 $\mathrm{mM}$ ), and the MEK1 [mitogen-activated protein (MAP) kinase kinase-1] inhibitor PD98059 (50 mM) were dissolved in DMSO. Protein kinase A inhibitory peptide 6-22 amide (1 $\mathrm{mM})$, the protein kinase A inhibitor Rp-cAMPS (50 mM), and cholera toxin (CTX) A subunit $(1 \mu \mathrm{g} / \mu \mathrm{l})$ were dissolved in $\mathrm{H}_{2} \mathrm{O}$. The $\mathrm{G}_{\mathrm{q}}$-binding protein designed to mimic the $\mathrm{C}$ terminus of the $\mathrm{G}_{\mathrm{q}} \alpha$ subunit and the $\mathrm{G}_{\mathrm{s}} \alpha$-binding protein designed to mimic the $C$ terminus of the $G_{s} \alpha$ subunit were synthesized by PeptidoGenic Research (Livermore, CA). The peptide sequence for $\mathrm{G}_{\mathrm{q}}$ peptide was Ac-LGLNLKEYNLV-OH, and the peptide sequence for $\mathrm{G}_{\mathrm{s}}$ peptide was CRMHLRQYELL. The peptides were also dissolved in $\mathrm{H}_{2} \mathrm{O}$. 1,2-Bis(o-aminophenoxyethane)- $N, N, N^{\prime}, N^{\prime}$-tetra-acetic acid (BAPTA) tetrasodium salt was dissolved in the internal solution at a $10 \mathrm{~mm}$ concentration. Aliquots of the stock solutions were stored as appropriate until needed.

Tissue preparation. On the day of experimentation, the animal was decapitated, its brain was removed from the skull, and the hypothalamus was dissected. The resultant hypothalamic block was mounted on a plastic cutting platform that was then secured in a vibratome well filled with ice-cold, oxygenated $\left(95 \% \mathrm{O}_{2}, 5 \% \mathrm{CO}_{2}\right.$ ) artificial CSF (aCSF) (in mм: $124 \mathrm{NaCl}, 26 \mathrm{NaHCO}_{3}, 10$ dextrose, $10 \mathrm{HEPES}, 5 \mathrm{KCl}, 2.6 \mathrm{NaH}_{2} \mathrm{PO}_{4}, 2$ $\mathrm{MgSO}_{4}$, and $\left.1 \mathrm{CaCl}_{2}\right)$. Four coronal slices $(350 \mu \mathrm{m})$ through the arcuate were cut. The slices were transferred to a multiwell auxiliary chamber containing oxygenated aCSF and kept there until electrophysiological recording after $\sim 2 \mathrm{hr}$.

Electrophysiology. Whole-cell patch recordings in voltage clamp were performed as described previously (Wagner et al., 2001). Slices were maintained briefly in a chamber perfused with warmed $\left(35^{\circ} \mathrm{C}\right)$, oxygenated aCSF containing the same constituents and respective concentrations, except for $\mathrm{CaCl}_{2}$, which was raised to $2 \mathrm{~mm}$. aCSF and all drug solutions were perfused via a peristaltic pump at a rate of $1.5 \mathrm{ml} / \mathrm{min}$. Drug solutions were prepared in $20 \mathrm{ml}$ syringes by diluting the appropriate stock solution with aCSF, and the flow was controlled via a three-way stopcock.

For whole-cell recordings, electrodes were fabricated from borosilicate glass $(1.5 \mathrm{~mm}$ outer diameter; World Precision Instruments, Sarasota, FL). Resultant electrodes were then filled with an internal solution containing $0.5 \%$ biocytin and consisting of the following (in $\mathrm{mM}$ ): $128 \mathrm{~K}^{+}$ gluconate, $10 \mathrm{NaCl}, 1 \mathrm{MgCl}_{2}$, 11 EGTA, 10 HEPES, $1.2 \mathrm{ATP}$, and $0.4 \mathrm{GTP}$ ( $\mathrm{pH}$ was adjusted to 7.3-7.4 with $1 \mathrm{~N} \mathrm{KOH}, 272-315 \mathrm{mOsm}$ ). Voltage pulses were amplified and passed through the electrode using an Axopatch 1D preamplifier (Axon Instruments, Union City, CA). The resultant current deflections were monitored using a digital oscilloscope (Tektronix 2230; Tektronix, Beaverton, OR). After the reduction of the current deflection, negative pressure was applied via a $5 \mathrm{ml}$ syringe connected by polyethylene tubing to the electrode to form a seal (>1G $\Omega$ ). After formation of a seal, intracellular access was achieved by suction, followed by perfusion with $1 \mu \mathrm{M}$ TTX for at least 4-6 min to block spontaneous firing and synaptic potentials before applying the $\mathrm{GABA}_{\mathrm{B}}$ receptor agonist baclofen (see Fig. 1). All of the responses to baclofen were measured in voltage clamp as outward currents $\left(V_{\text {hold }}=-60 \mathrm{mV}\right)$, and only those cells that showed $<10 \%$ change in access resistance (ac- 
cess resistances ranged from 20 to $30 \mathrm{M} \Omega$ ) throughout the recording were included in this study. Membrane currents underwent analog-todigital conversion via a Digidata 1200 interface coupled to pClamp 7.0 (Axon Instruments). Low-pass filtering of the currents was conducted at a frequency of $2 \mathrm{kHz}$. The liquid junction potential was $-10 \mathrm{mV}$ and was corrected for in subsequent data analysis.

Post hoc identification of hypothalamic arcuate neurons. After electrophysiological recording, the slices were fixed with $4 \%$ paraformaldehyde in Sorensen's phosphate buffer, $\mathrm{pH}$ 7.4, for $120 \mathrm{~min}$, immersed overnight in $20 \%$ sucrose dissolved in Sorensen's buffer, and then frozen in OCT embedding medium and prepared for immunocytochemistry as described previously (Kelly and Rønnekleiv, 1994). Briefly, coronal sections $(20 \mu \mathrm{m})$ were cut on a cryostat (model 1720 Digital Cryostat; Leitz, Wetzlar, Germany) and mounted on Fisher SuperFrost Plus slides. Sections were washed for $5 \mathrm{~min}$ with $0.1 \mathrm{M}$ sodium phosphate buffer, $\mathrm{pH}$ 7.4, and then streptavidin-Cy2 (1:1000; Jackson ImmunoResearch, West Grove, PA) was applied for $2 \mathrm{hr}$. The reaction was terminated by washing with buffer. The slices were scanned for the injected neuron with a Nikon (Melville, NY) Eclipse 800 fluorescence microscope. After localization of the biocytin-filled neurons, the slides containing the appropriate sections were processed for the presence of tyrosine hydroxylase (TH) or $\beta$-endorphin using fluorescence immunohistochemistry as described previously (Kelly and Rønnekleiv, 1994). Briefly, the sections with the biocytin-identified neurons were incubated overnight with a monoclonal TH antibody at 1:10,000 (Diasorin, Stillwater, MN) or with a polyclonal $\beta$-endorphin antibody at 1:5000 (Dave et al., 1985) and washed in $0.1 \mathrm{M}$ phosphate buffer, followed by incubation with a goat anti-mouse IgG-Cy3 at 1:500 or donkey anti-rabbit IgG-Cy3 at 1:500, respectively (Jackson ImmunoResearch). The sections were washed with sodium phosphate buffer, and coverslips were applied using a glycerolglycine buffer containing $5 \% \mathrm{~N}$-propylgallate. Immunostained cells were photographed using a Nikon microscope.

Estrogen receptor binding assays. The relative binding affinity of compounds for $\mathrm{ER} \alpha$ and $\mathrm{ER} \beta$ was determined using a spin column assay with commercially available full-length forms of both $\operatorname{ER} \alpha$ and $\operatorname{ER} \beta$ (PanVera, Madison, WI). Receptor was added to a final concentration of 15 nм to a solution containing $10 \mathrm{~mm}$ Tris, $\mathrm{pH} 7.5,10 \%$ glycerol, $2 \mathrm{~mm}$ DTT, $1 \mathrm{mg} / \mathrm{ml} \mathrm{BSA}$, and $3 \mathrm{~nm}\left[2,4,6,7,16,17-{ }^{3} \mathrm{H}\right]$ estradiol at $4^{\circ} \mathrm{C}$. Next, $100 \mu \mathrm{l}$ of the solution was added to $1 \mu$ lof the ligand in ethanol, mixed gently by pipetting, and incubated at $4^{\circ} \mathrm{C}$ overnight. The mixture was then applied to a micro spin column containing G-25 Sephadex (Harvard Apparatus, Holliston, MA) equilibrated in binding buffer (minus tritiated estradiol) according to the instructions of the manufacturer. Bound estradiol was separated from free ligand by spinning at $2000 \times g$ for 4 min at room temperature. The filtrate was then added to $2.5 \mathrm{ml}$ of scintillant and counted in a liquid scintillation counter. A binding curve was fitted using a single binding site competition model with the Prism statistical analysis software package (GraphPad Software, San Diego, CA). The SD was determined to be $<0.2 \mathrm{log}$ units from the $\mathrm{EC}_{50}$ value. Percentage relative binding affinity was then determined by dividing the $\mathrm{IC}_{50}$ determined for unlabeled estradiol by the ligand $\mathrm{IC}_{50}$ and multiplying by 100 .

Dispersed single-cell RT-PCR. Guinea pig $350 \mu \mathrm{m}$ coronal hypothalamic slices were cut on a vibratome from caudal to rostral and placed in an auxiliary chamber containing oxygenated aCSF. The slices were allowed to recover for $1-2 \mathrm{hr}$ in the chamber before dispersion. The arcuate nucleus of the hypothalamus was microdissected and incubated in 2-3 $\mathrm{ml}$ of HBSS containing the following: $1.26 \mathrm{mM} \mathrm{CaCl}_{2}, 1 \mathrm{mM} \mathrm{MgSO}_{4}, 5.37$ mм KCl, $0.44 \mathrm{~mm} \mathrm{KH}_{2} \mathrm{PO}_{4}, 136.89 \mathrm{~mm} \mathrm{NaCl}, 0.34 \mathrm{~mm} \mathrm{Na}_{2} \mathrm{HPO}_{4}, 5.55$ mM D-glucose, and 15 mM HEPES in DEPC-treated water, pH 7.3 (300 $\mathrm{mOsm}$ ), containing $1 \mathrm{mg} / \mathrm{ml}$ protease XIV (Sigma, St. Louis, MO) for $\sim 15 \mathrm{~min}$ at $37^{\circ} \mathrm{C}$. The tissue was then washed four times in 1 vol of low-calcium aCSF and two times in HBSS. The cells were isolated by trituration with flame-polished Pasteur pipettes, dispersed on a dish, and perfused continuously with HBSS at a rate of $1.5 \mathrm{ml} / \mathrm{min}$. Cells were visualized using a Nikon inverted microscope, and individual neurons were patched and harvested into the patch pipette by applying negative pressure. The content of the pipette was expelled into a siliconized microcentrifuge tube containing $5 \mu \mathrm{l}$ of the following solution: $0.5 \mu \mathrm{l}$ of $10 \times$ buffer (100 mm Tris-HCl, $500 \mathrm{~mm} \mathrm{KCl,} \mathrm{1 \%} \mathrm{Triton} \mathrm{X-100;} \mathrm{Promega,}$
Madison, WI), $15 \mathrm{U}$ of RNasin (Promega), $0.5 \mu \mathrm{l}$ of $100 \mathrm{~mm}$ DTT, and DEPC-treated water.

In addition, hypothalamic tissue was homogenized, and total RNA was extracted using the RNeasy kit (Qiagen, Valencia, CA) according to the protocol of the manufacturer. The harvested cell solution and $25 \mathrm{ng}$ of hypothalamic total RNA in $1 \mu \mathrm{l}$ were denatured for $5 \mathrm{~min}$ at $65^{\circ} \mathrm{C}$ and cooled on ice for $5 \mathrm{~min}$, and then single-stranded cDNA was synthesized from cellular RNA by adding $50 \mathrm{U}$ of murine leukemia virus reverse transcriptase (Applied Biosystems, Foster City, CA), $1.5 \mu$ l of $10 \times$ buffer, $2 \mathrm{mM} \mathrm{MgCl}_{2}, 0.2 \mu \mathrm{l}$ of deoxynucleotide triphosphates (dNTPs), $15 \mathrm{U}$ of RNasin, $10 \mathrm{~mm}$ DTT, $100 \mathrm{ng}$ f random hexamers, and DEPC-treated water to a final volume of $20 \mu$ l. Cells and tissue RNA used as negative controls were processed as described above but without reverse transcriptase. The reaction mixtures were incubated at $42^{\circ} \mathrm{C}$ for $60 \mathrm{~min}$, denatured at $99^{\circ} \mathrm{C}$ for $5 \mathrm{~min}$, and cooled on ice for $5 \mathrm{~min}$.

PCR was performed using $3 \mu \mathrm{l}$ of cDNA template from each RT reaction in a $30 \mu \mathrm{l}$ of PCR reaction volume containing the following: $3 \mu \mathrm{l}$ of $10 \times$ buffer, $2.4 \mu \mathrm{l}$ of $\mathrm{MgCl}_{2}$ [ $2 \mathrm{~mm}$ final concentration for TH, POMC, $\mathrm{GABA}_{\mathrm{B}}$ receptor $2\left(\mathrm{GABA}_{\mathrm{B}} \mathrm{R} 2\right), \mathrm{PKC} \delta$, adenylyl cyclase VII (AC VII), and glyceraldehyde-3-phospate dehydrogenase (GAPDH)], or $3.6 \mu \mathrm{l}$ of $\mathrm{MgCl}_{2}$ (3 mM final concentration for GAD), $0.2 \mathrm{~mm}$ dNTPs, $0.2 \mu \mathrm{M}$ forward and reverse primers, $2 \mathrm{U}$ of Taq DNA polymerase (Promega), and $0.22 \mu \mathrm{g}$ of TaqStart antibody (Clontech, Palo Alto, CA). Taq DNA polymerase and TaqStart antibody were combined and incubated at room temperature for $5 \mathrm{~min}$, and the remainder of the reaction contents were added to the tube and incubated at $94^{\circ} \mathrm{C}$ for $2 \mathrm{~min}$. Then, each reaction went through 60 cycles ( 35 cycles for GAPDH) of amplification according to the following protocols: $94^{\circ} \mathrm{C}, 45 \mathrm{sec} ; 55^{\circ} \mathrm{C}(\mathrm{GAD}), 57^{\circ} \mathrm{C}$ (PKC $\delta), 58^{\circ} \mathrm{C}\left(\mathrm{GABA}_{\mathrm{B}}-\mathrm{R} 2\right), 60^{\circ} \mathrm{C}(\mathrm{TH}$ and adenylyl cyclase VII $), 61^{\circ} \mathrm{C}$ (POMC), $63^{\circ} \mathrm{C}(\mathrm{GAPDH}) 45 \mathrm{sec} ; 72^{\circ} \mathrm{C}, 1 \mathrm{~min} 10 \mathrm{sec}$; with a final $72^{\circ} \mathrm{C}$ extension for $5 \mathrm{~min}$. Ten microliters of the PCR products were visualized with ethidium bromide on a $1.5 \%$ agarose gel.

All of the primers were synthesized by Invitrogen (Carlsbad, CA) and were as follows: guinea pig $\mathrm{GAD}_{65}, 207$ bp product, forward primer 5'-GGCTCTGGTGATGGAATA-3', reverse primer 5' ${ }^{\prime}$-CAGAATCACGCTGTCTGTT-3'; guinea pig TH, 223 bp product, forward primer 5'-TCCACGTTATACTGGTTCAC-3', reverse primer 5'-TTGCATCACTGAAGCTCTC-3'; guinea pig $\mathrm{GABA}_{\mathrm{B}}-\mathrm{R} 2,241$ bp product, forward primer $5^{\prime}$-TGTTTGTGCCAAAGCTCATC-3' reverse primer $5^{\prime}$ GTGTCTTGCAGTTGCATAGT-3'; guinea pig POMC (GenBank accession number S78260), 344 bp product, forward primer (bases $40-$ 60) 5' -CTGGCCTTGCTGCTTCAGAT-3' reverse primer (bases 383363) 5' -ATGGAGTAGGAGCGCTTGTC-3'; guinea pig GAPDH, 212 bp product (GenBank accession number CPU51572), forward primer 5'CATCCACTGGTGCTGCCAAG-3', reverse primer 5'-GTCCTCGGTGTAGCCCAAGA-3'; human protein kinase $C \delta, 251$ bp product (GenBank accession number L07861) forward primer (bases 1127-1147) 5'-AAAGGCAGCTTCGGGAAGGT-3', reverse primer (bases 1377-1357) $5^{\prime}$-TGGATGTGGTACATCAGGTC-3'; and guinea pig adenylyl cyclase VII, 235 bp product, forward primer $5^{\prime}$-CTGTTCGGCAAGTTTGACCAG-3', reverse primer 5'-TGACGCCACACAGCACATT-3'.

Statistical analyses. Comparisons between groups were performed using a one-way ANOVA [with post hoc (Newman-Keuls) paired analysis]. Differences were considered statistically significant if the probability of error was $<5 \%$.

\section{Results}

\section{$E_{2}$ and $S E R M s$ rapidly attenuate the $G A B A_{B}$ response in} hypothalamic dopamine and POMC neurons

Whole-cell recordings were made in arcuate neurons $(n=195)$ from ovariectomized female guinea pigs (Fig. 1). A subgroup of these neurons ( $n=55$ ) was identified using dual-labeling immunocytochemistry (Fig. 2). This revealed that $41 \%$ of the cells were $\mathrm{TH}$ positive (i.e., dopamine neurons) and $39 \%$ were $\beta$ endorphin positive (i.e., POMC neurons). Moreover, on the basis of dual-immunocytochemical staining and in situ hybridization for $\mathrm{GAD}_{65}$, a subgroup of arcuate dopamine neurons coexpress GABA (O. K. Rønnekleiv, unpublished findings), which was sub- 
stantiated by the scRT-PCR data (see below). For the electrophysiology analysis, only cells with gigaohm or better seals were included in this study. The mean resting membrane potential was $-54.3 \pm 0.4 \mathrm{mV}$ at a $0 \mathrm{pA}$ holding current, and the mean input resistance was $1.9 \pm 0.3 \mathrm{G} \Omega$. Moreover, $50 \%$ of A12 dopamine neurons exhibited a T-type $\mathrm{Ca}^{2+}$ current and a hyperpolarization-activated cation current $\left(I_{\mathrm{h}}\right)$, as we described previously (Loose et al., 1990). Seventy-one percent of the POMC neurons exhibited $I_{\mathrm{h}}$ and a transient outward $\mathrm{K}^{+}$current $\left(I_{\mathrm{A}}\right)$, as we described previously (Kelly et al., 1990). Therefore, the passive membrane properties measured with wholecell patch recording are similar to what we described using single-electrode voltageclamp recordings (Kelly et al., 1990; Loose et al., 1990).

We used the whole-cell recording method to measure the rapid effects of $E_{2}$ on the activation of the GIRK conductance by the $\mathrm{GABA}_{\mathrm{B}}$ receptor agonist baclofen. We showed previously that $\mathrm{E}_{2}$ rapidly attenuates both $\mu$-opioid and $\mathrm{GABA}_{\mathrm{B}}$ receptormediated responses in hypothalamic arcuate neurons (Lagrange et al., 1994, 1996, 1997). Therefore, for measuring $\mathrm{E}_{2}$ modulation of the $\mathrm{GABA}_{\mathrm{B}}$ response, we used an $\mathrm{EC}_{50}$ concentration $(5 \mu \mathrm{M})$ of baclofen and the protocol depicted in Figure 1. A robust outward current was measured in response to baclofen that subsided after washout (Fig. $3 \mathrm{~A}, \mathrm{H}$ ). The application of baclofen $20 \mathrm{~min}$ later elicited the same robust response, suggesting that desensitization and rundown were not occurring in response to successive applications of $5 \mu \mathrm{M}$ baclofen. However, if $\mathrm{E}_{2}$ (100 nM) was applied during the interim period (i.e., after the washout of the first application of baclofen), there was a significant $(p<0.005)$ decrease of $41 \%$ in the response to a second application of baclofen (Fig. $3 B, H)$. Current-voltage relationships generated before and during the application of $100 \mathrm{nM} \mathrm{E}_{2}$ showed that this steroid did not change the reversal potential for the baclofen-mediated response: control $E_{\mathrm{ba}}$ clofen, $-88.8 \pm 3.6 \mathrm{mV}, n=13$; versus after $\mathrm{E}_{2} E_{\text {baclofen}},-85.4 \pm 3.9 \mathrm{mV}, n=12$ (Fig. $1 C, D)$. The effects of $\mathrm{E}_{2}$ were stereospecific such that the biologically inactive stereoisomer $17 \alpha$-estradiol (100 nM) had no effect on the baclofen response (Fig. 3C,H). Furthermore, the effects of $\mathrm{E}_{2}$ were blocked by the anti-estrogen ICI 182,780 when coperfused with $\mathrm{E}_{2}$ (Fig. $3 \mathrm{H}$ ). Treatment with ICI 182,780 alone had no effect on the baclofen response (data not shown).

We next investigated the cellular localization of this estrogen receptor using the membrane-impermeable estrogen conjugate $\mathrm{E}_{2}-\mathrm{BSA}$. Interestingly, $\mathrm{E}_{2}-\mathrm{BSA}(100 \mathrm{nM})$ was fully efficacious in
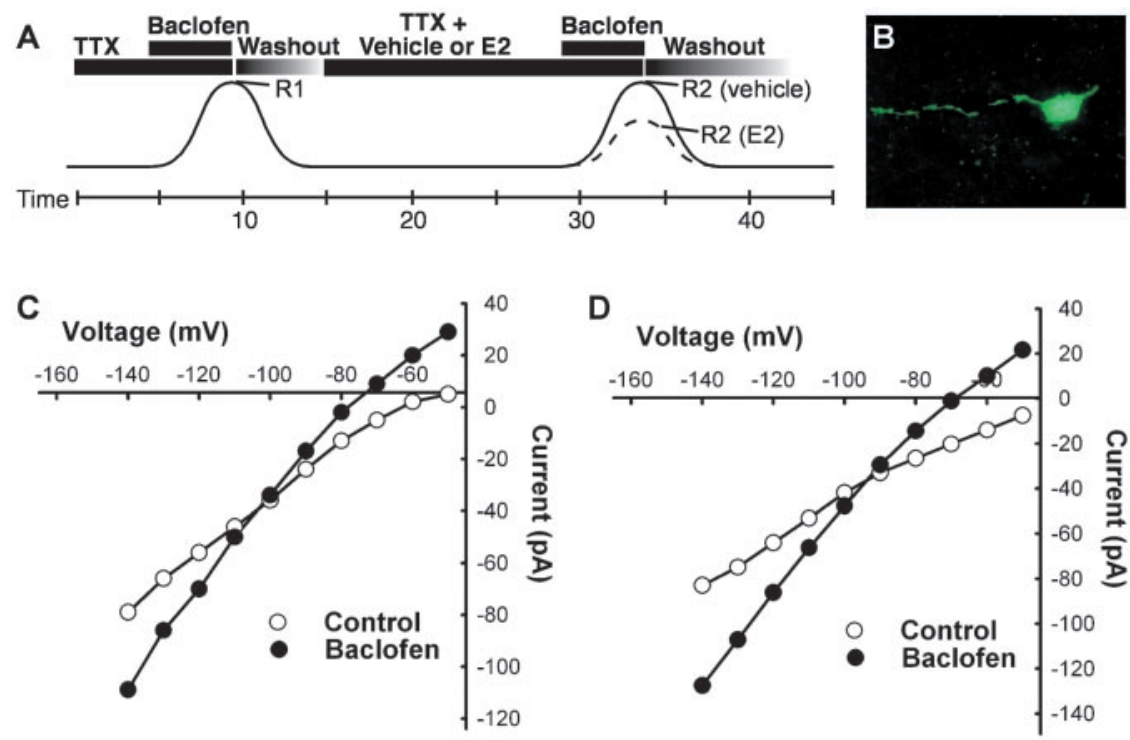

Figure 1. $17 \beta$-Estradiol and SERMs attenuate the $\mathrm{GABA}_{\mathrm{B}}$ response in hypothalamic neurons. $A$, Schematic showing the protocol for drug administration in the whole-cell patch voltage-clamp experiments $\left(V_{\text {hold }},-60 \mathrm{mV}\right)$. After seals were formed and the whole-cell configuration was obtained, slices were perfused with TTX $(1 \mu \mathrm{m})$ for $5 \mathrm{~min}$. The first GABA $\mathrm{A}_{\mathrm{B}}$ receptor-mediated response was generated by perfusing baclofen (at $\mathrm{EC}_{50}$ concentration of $5 \mu \mathrm{M}$ ) until a steady-state outward current was obtained (R1). After drug washout, the current returned to its predrug resting level. The cells were then treated with $\mathrm{E}_{2}$ and/or other drugs for $15 \mathrm{~min}$, baclofen $(5 \mu \mathrm{m})$ was perfused again, and R2 was measured. The effects of estrogen or other drugs on the baclofen response are expressed as a percentage of R2 over R1. $B$, An example of a biocytin-filled neuron after whole-cell patch-clamp recording for $13 \mathrm{~min}$, illustrating the extent of the biocytin labeling. The slice was fixed immediately after the recording. $C$, The prebaclofen and postbaclofen $(5 \mu \mathrm{m}) \mathrm{I} / \mathrm{V}$ relationships from a dopamine neuron. The reversal potential for the outward current was close to the predicted equilibrium potential for potassium. $D$, The prebaclofen and postbaclofen $I / V$ relationships after $E_{2}$ treatment in another cell, illustrating the same reversal potential for the baclofen response. I/Vs were done before and after each drug treatment, and none of the drug treatments had any effect on the reversal potential for the baclofen response.
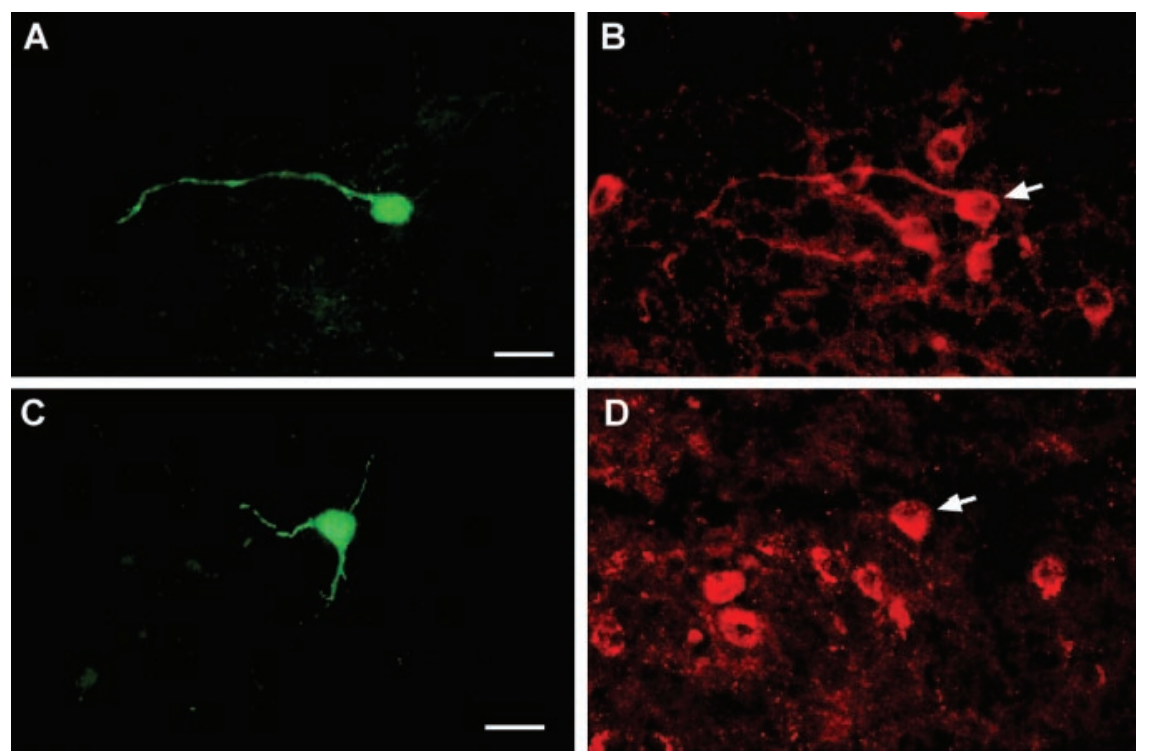

Figure 2. Double labeling of dopamine and POMC neurons. Representative dopamine $(A, B)$ and POMC $(C, D)$ neurons that responded to estrogen. Arcuate neurons were filled with biocytin during the whole-cell recording. $A$, Biocytin-streptavidin-Cy2 labeling of fusiform arcuate neuron. Scale bar, $20 \mu \mathrm{m}$. B, Immunocytochemical staining of TH in the same neuron (arrow). $C$, Biocytin-streptavidin-Cy2 labeling of a small pyramidal arcuate neuron. Scale bar, $20 \mu \mathrm{m}$. D, Immunocytochemical staining of $\beta$-endorphin in the same neuron (arrow).

inhibiting the baclofen response, indicating that this estrogen receptor-mediated response is initiated at the plasma membrane (Fig. $3 D, H$ ). We checked the integrity of the $\mathrm{E}_{2}-\mathrm{BSA}$ preparation by performing an $\mathrm{E}_{2}$ radioimmunoassay of the slice perfusate. We 
A

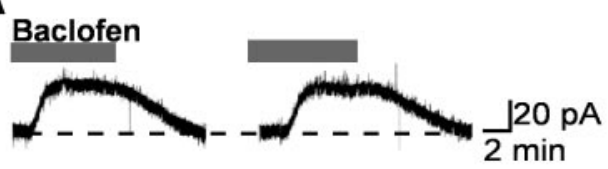

B

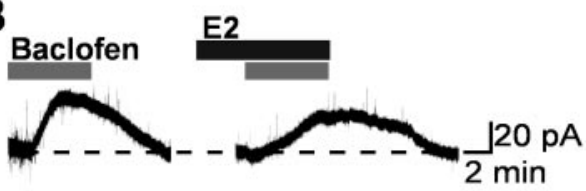

C Baclofen $17 \alpha-\mathrm{E2}$

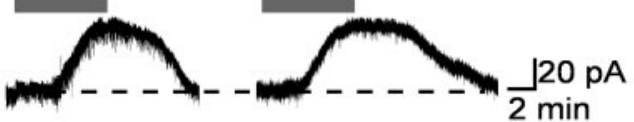

D

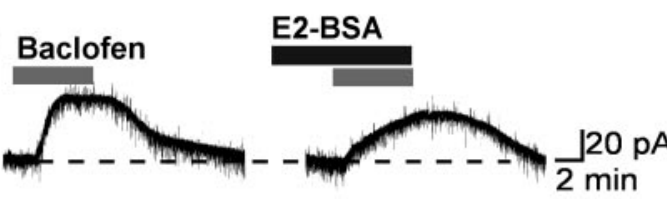

E

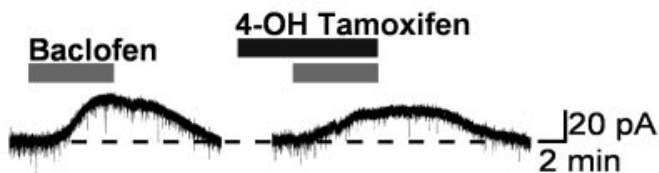

$F_{\text {Baclofen }}$

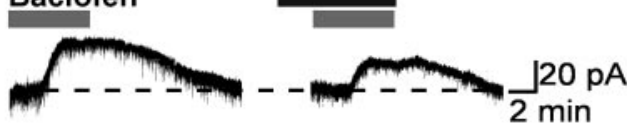<smiles>[R17]C1(Br)CCC2C3CCc4cc(O)ccc4C3CCC21C</smiles>

17 $\beta$-Estradiol: $\mathrm{R}_{1}=\mathrm{OH} ; \mathrm{R}_{2}=\mathrm{H}$

$17 \alpha$-Estradiol: $\mathrm{R}_{1}=\mathrm{H} ; \mathrm{R}_{2}=\mathrm{OH}$<smiles>C[C@H]1Cc2cc(O)ccc2C2CC[C@]3(C)C(CC[C@H]3O)C21</smiles>

ICI 182,780

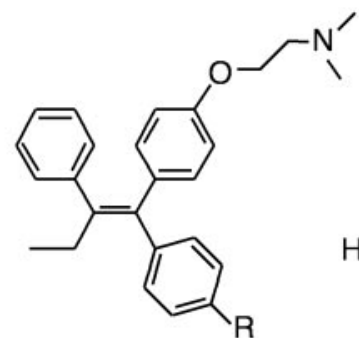

Tamoxifen: $\mathrm{R}=\mathrm{H}$

4-Hydroxytamoxifen: $\mathrm{R}=\mathrm{OH}$

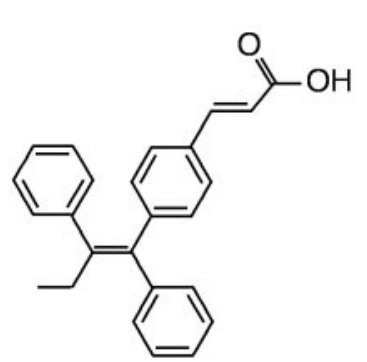

GW5638

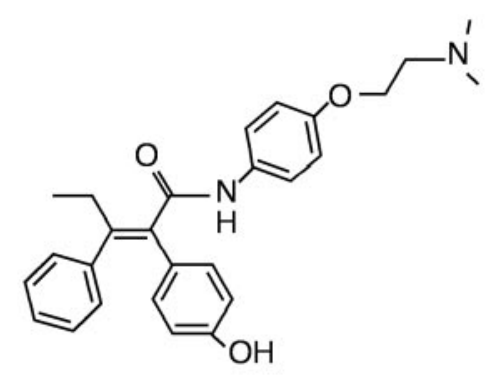

STX

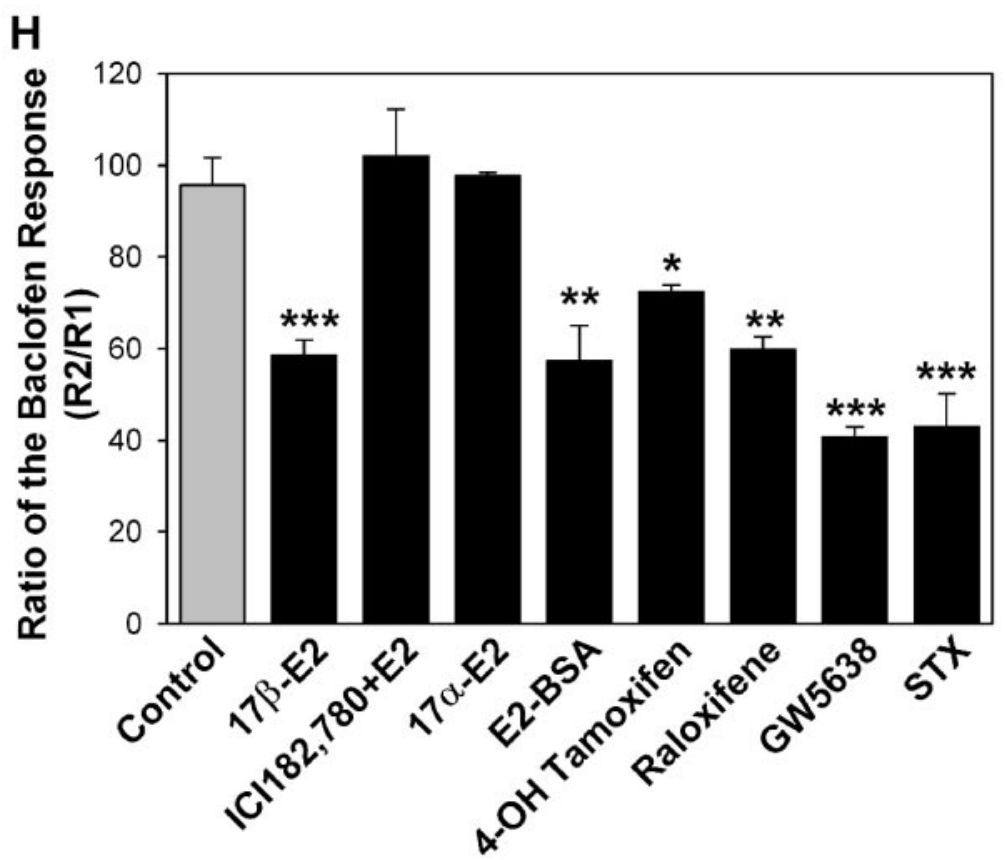

Figure 3. Estrogen and SERMs rapidly attenuate the $G A B A_{B}$ response. $A-F$, Representative traces of the $G A B A_{B}$ responses before and after steroid treatment. Experiments were conducted as described in Figure 1. $G$, The chemical structures of $E_{2}$ and the SERMs. $H$, Bar graphs summarizing the effects of $E_{2}$ and SERMs on the baclofen response. $E_{2}\left(100\right.$ nm) attenuated the GABA $A_{B}$ receptor-mediated outward current by $41 \%$. The inhibitory effects of $E_{2}$ on the baclofen response were blocked by the estrogen receptor antagonist ICl $182,780(1 \mu \mathrm{m})$. $\mathrm{E}_{2}-\mathrm{BSA}(100 \mathrm{nM}), 4-0 \mathrm{H}$ tamoxifen $(1 \mu \mathrm{M})$, raloxifene $(1 \mu \mathrm{M})$, GW-5638 $(1 \mu \mathrm{M})$, and STX $(10 \mathrm{~nm})$ also inhibited the baclofen response; however, $17 \alpha-\mathrm{E}_{2}(1 \mu \mathrm{M})$ had no effect. Error bars represent the mean \pm SEM of $4-11$ cells tested per group. ${ }^{*} p<0.05,{ }^{* *} p<0.01$, and ${ }^{* * *} p<0.005$, versus vehicle control group. 
Table 1. Relative binding affinities of ligands to full-length ER $\alpha$ or ER $\beta$

\begin{tabular}{lcc}
\hline & \multicolumn{2}{l}{ RBA } \\
\cline { 2 - 3 } Ligand & ER $\alpha$ & ER $\beta$ \\
\hline $17 \beta$-Estradiol & 100 & 100 \\
4-Hydroxytamoxifen & 36 & 43 \\
Raloxifene & 34 & 76 \\
GW-5638 & 5 & 8 \\
STX & $4.3 \mathrm{E}-6$ & $9.0 \mathrm{E}-6$
\end{tabular}

Relative binding affinities (RBA) are expressed as a percentage of the potency of $17 \beta$-estradiol. Under the experimental conditions described in Materials and Methods, $17 \beta$-estradiol was found to have an $\mathrm{IC}_{50}$ of $5 \mathrm{~nm}$ for ER $\alpha$ and 3 nм for $\operatorname{ER} \beta$.

found no unbound $\mathrm{E}_{2}$ in the media (data not shown), indicating that $\mathrm{E}_{2}-\mathrm{BSA}$ conjugate did not contain contamination-free $\mathrm{E}_{2}$.

We also characterized the estrogen receptor by using several SERMs. Tamoxifen $(1 \mu \mathrm{M})$ was inactive $(p>0.05$ vs control) and did not attenuate the effects of $E_{2}$ on the baclofen activation of GIRK (R2/R1 for $\mathrm{E}_{2}, 58.6 \pm 3.4 \%, n=10$; vs tamoxifen plus $\mathrm{E}_{2}$, $60.4 \pm 6.6 \%, n=5)$. However, $4-\mathrm{OH}$ tamoxifen $(1 \mu \mathrm{M})$ did partially mimic the actions of $\mathrm{E}_{2}$ by blocking the baclofen response by $25 \%$ (Fig. $3 E, H$ ). Because $4-\mathrm{OH}$ tamoxifen always exists as an $\mathrm{E} / \mathrm{Z}$ mixture of olefin isomers (Katzenellenbogen et al., 1985), we suspect that only one of the isomers is active at mediating this novel estrogen response. Raloxifene ( $1 \mu \mathrm{M})$, another SERM with a hydroxylated aromatic ring, mimicked completely the actions of $\mathrm{E}_{2}$ in terms of efficacy in the suppression of the baclofen response (Fig. $3 H$ ). In contrast, the nonhydroxylated SERM GW-5638, which structurally resembles the triphenylethylene core of tamoxifen, was found to be significantly more efficacious than $\mathrm{E}_{2}$ at inhibiting GIRK channel activation by baclofen (Fig. 3H).

\section{STX is a SERM devoid of nuclear ER activity that selectively attenuates rapid responses}

All of the above-mentioned compounds are high-affinity ligands for the nuclear estrogen receptors (Table 1), which complicates the interpretation of the observed pharmacology and makes it difficult to exclude unequivocally a role for nuclear ERs. Therefore, we next tested a novel diphenylacrylamide compound (STX) (Fig. 3G), which is a close structural analog of 4-OH tamoxifen. However, unlike 4-OH tamoxifen, STX is geometrically stable and does not exist as a mixture of E/Z olefin isomers. An additional distinction between STX and other SERMs is that STX has an $\sim 1$ million-fold reduced binding affinity for the nuclear $\mathrm{ER} \alpha$ or $\mathrm{ER} \beta$ compared with that of $\mathrm{E}_{2}$ (Table 1 ). In addition, this compound has no uterotropic actions, even at five times the dose of $\mathrm{E}_{2}$ (Fig. 4), confirming in vivo that STX has no $4-\mathrm{OH}$ tamoxifen-like estrogenic activity mediated by the nuclear ERs. However, in the whole-cell electrophysiological assay, $10 \mathrm{~nm}$ STX was as efficacious as $100 \mathrm{nM} \mathrm{E}_{2}$ in attenuating the $\mathrm{GABA}_{\mathrm{B}}$ response (Fig. $3 F, H)$.

\section{The rapid effect of $E_{2}$ on the $\mathrm{GABA}_{B}$ response involves protein} kinase A

We next examined the involvement of specific signaling proteins in the $\mathrm{E}_{2}$-mediated modulation of $\mathrm{GABA}_{\mathrm{B}}$. If activation of the PKA pathway is involved, then the effect of $E_{2}$ on $G_{A B A}$ responses should be blocked by inhibiting PKA and mimicked by stimulating PKA. To test this, we applied selective PKA activators and inhibitors. As shown in Figure 5, $A$ and $E$, forskolin $(10 \mu \mathrm{M})$ could mimic the actions of $E_{2}$ to attenuate the $\mathrm{GABA}_{\mathrm{B}}$ response. However, the specific PKA inhibitor $\mathrm{H}-89(10 \mu \mathrm{M})$ blocked the $\mathrm{E}_{2}$-induced suppression of the $\mathrm{GABA}_{\mathrm{B}}$ response (Fig. $5 B, E$ ). To
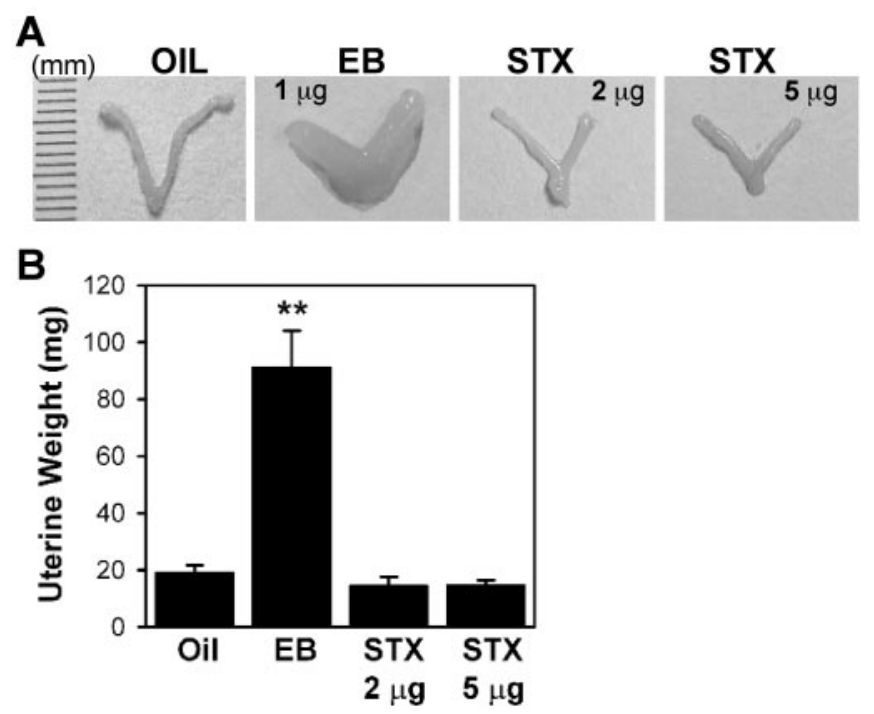

Figure 4. Uteri are enlarged after estradiol treatment but not after STX or oil vehicle treatment. After a $48 \mathrm{hr}$ treatment period, the uteri of wild-type (57BL/6 mice were collected and examined. $A$, In $\mathrm{E}_{2}$-treated mice, there was a noticeable increase in uterine size after estradiol benzoate (EB) compared with oil vehicle or STX treatment. $B$, Bar graph shows the uterine weights. ${ }^{* *} p<0.01$ versus oil-treated females ( $n=3-5$ mice per group).

confirm the involvement of PKA in $\mathrm{E}_{2}$ modulation of $\mathrm{GABA}_{\mathrm{B}}$ responses further, we dialyzed neurons with the specific PKAinhibitory peptide PKI (PKA inhibitor 6-22 amide, $20 \mu \mathrm{M}$ ) or the nonhydrolyzable cAMP analog Rp-cAMPS $(200 \mu \mathrm{M})$ that blocks PKA activation. After $\sim 15 \mathrm{~min}$ of dialysis with PKI or RpcAMPS, the $E_{2}$-induced reduction of the $G_{A B A}$ response was abolished (Fig. 5C,E). CTX, which is a bacterial exotoxin secreted by vibrio cholerae, elevates intracellular cAMP levels in a variety of tissues by ADP ribosylating the $\mathrm{G}$-protein $\mathrm{G}_{\mathrm{s}}$, thereby stimulating adenylyl cyclase activity in an apparently irreversible manner. Intracellular dialysis with the active unit of CTX into individual cells occluded the rapid inhibition of $\mathrm{GABA}_{\mathrm{B}}$ response by estrogen (Fig. $5 D, E$ ). These results indicate that the suppression of the $\mathrm{GABA}_{\mathrm{B}}$ response by $\mathrm{E}_{2}$ requires the activation of PKA.

\section{Attenuation of the $\mathrm{GABA}_{\mathrm{B}}$ response involves protein kinase $\mathbf{C} \boldsymbol{\delta}$}

We next examined whether activation of PKC is also critical for $\mathrm{E}_{2}$ modulation of the $\mathrm{GABA}_{\mathrm{B}}$ response using several selective PKC inhibitors. The first, bisindolymaleimide, is a selective inhibitor of PKC that does not distinguish among the conventional, novel, and atypical isoforms of PKC. The second, Gö6976, is a selective inhibitor of the conventional PKC isoforms (MartinyBaron et al., 1993; Way et al., 2000). Treatment of neurons with BIS nearly eliminated the effects of $\mathrm{E}_{2}$ (Fig. 6A,E). In contrast, Gö6976 treatment was without effect (Fig. 6E). Indeed, when similar experiments were performed after replacing intracellular EGTA with 10 mM BAPTA, a calcium buffer with similar $\mathrm{Ca}^{2+}$ affinity as EGTA but a much faster on rate, the estrogen inhibition of the $\mathrm{GABA}_{\mathrm{B}}$ response was still observed (Fig. $6 \mathrm{~B}, E$ ). Because conventional isoforms of $\mathrm{PKC}$ are unlikely to be active with this level of calcium buffering, these results also support a role for $\mathrm{a} \mathrm{Ca}^{2+}$-independent, novel PKC isoform in mediating the effects of estrogen. Finally, the selective PKC $\delta$ inhibitor rottlerin $(5 \mu \mathrm{M})$ completely blocked the ability of $E_{2}$ to inhibit the $G_{A B A}$ response in hypothalamic neurons (Fig. 6C,E). 
A

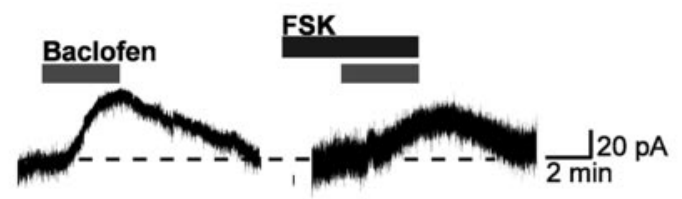

B
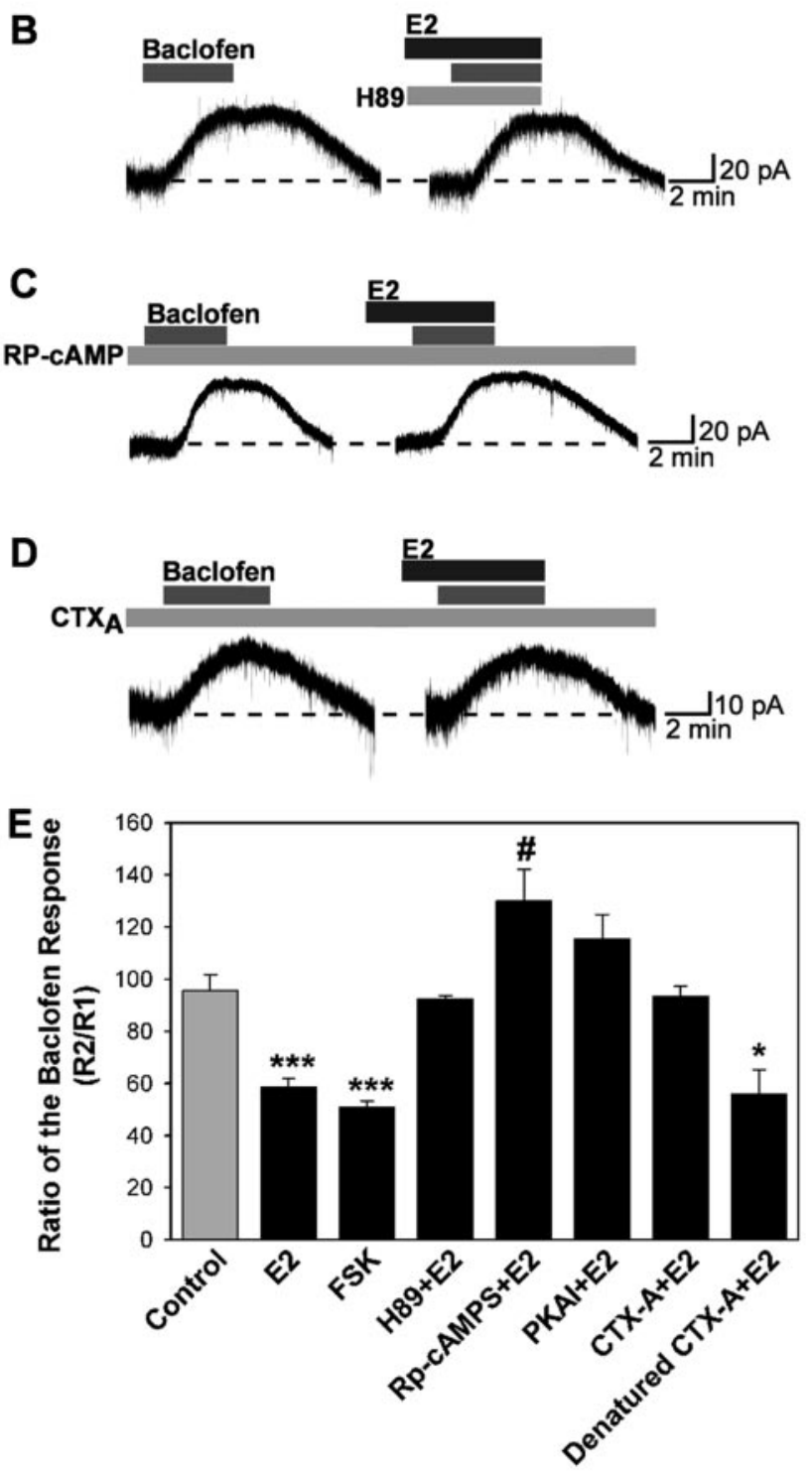

Figure 5. $E_{2}$ attenuation of the $G A B A_{B}$ response involves protein kinase A. $A-D$, Representative traces of the baclofen responses in the presence of PKA activators or inhibitors. Experiments were conducted as described in Figure 1, except that cells were dialyzed for $15 \mathrm{~min}$ before the first baclofen application with Rp-cAMPS $(200 \mu \mathrm{M})$, PKA inhibitor 6-22 amide (PKAl; 20 $\mu \mathrm{M})$, CTXA subunit (CTX-A; $10 \mu \mathrm{g} / \mathrm{ml})$, or denatured (TX A subunit $\left(10 \mu \mathrm{g} / \mathrm{ml}, 100^{\circ} \mathrm{C}, 10 \mathrm{~min}\right)$. H-89 (10 $\mu \mathrm{M}$ ) and forskolin (FSK; $10 \mu \mathrm{M}$ ) were bath perfused. E, Bar graphs summarizing the effects of PKA drugs. The PKA activator forskolin could mimic the effects of $E_{2}$, and the specific PKA inhibitors H-89 $(10 \mu \mathrm{M})$, Rp-cAMPS, and PKAl could block the effects. CTX A subunit could occlude the attenuation of the baclofen response by $E_{2}$; however, the denatured CTX A subunit could not. Error bars represent the mean \pm SEM of $4-11$ cells tested per group. ${ }^{*} p<0.05$, ${ }^{\#} p<0.05$, and ${ }^{* * *} p<0.005$ versus vehicle control; (TX A subunit plus $\mathrm{E}_{2}$ versus denatured CTX A subunit plus $\mathrm{E}_{2}, p<0.05$.

Inhibition of the $\mathrm{GABA}_{\mathrm{B}}$ response by $\mathrm{E}_{2}$ involves $\mathrm{G} \boldsymbol{\alpha}_{\mathrm{q}}$ Although the specific PKC inhibitor BIS blocked the $\mathrm{E}_{2}$ effect, forskolin $(10 \mu \mathrm{M})$ was found to mimic the effects of estrogen in the presence of BIS blockade (Fig. $6 D, E$ ). This indicated that the
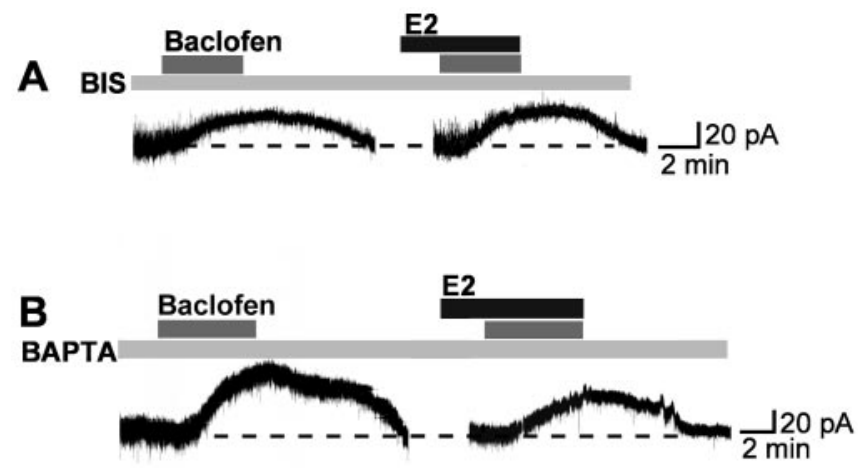

C
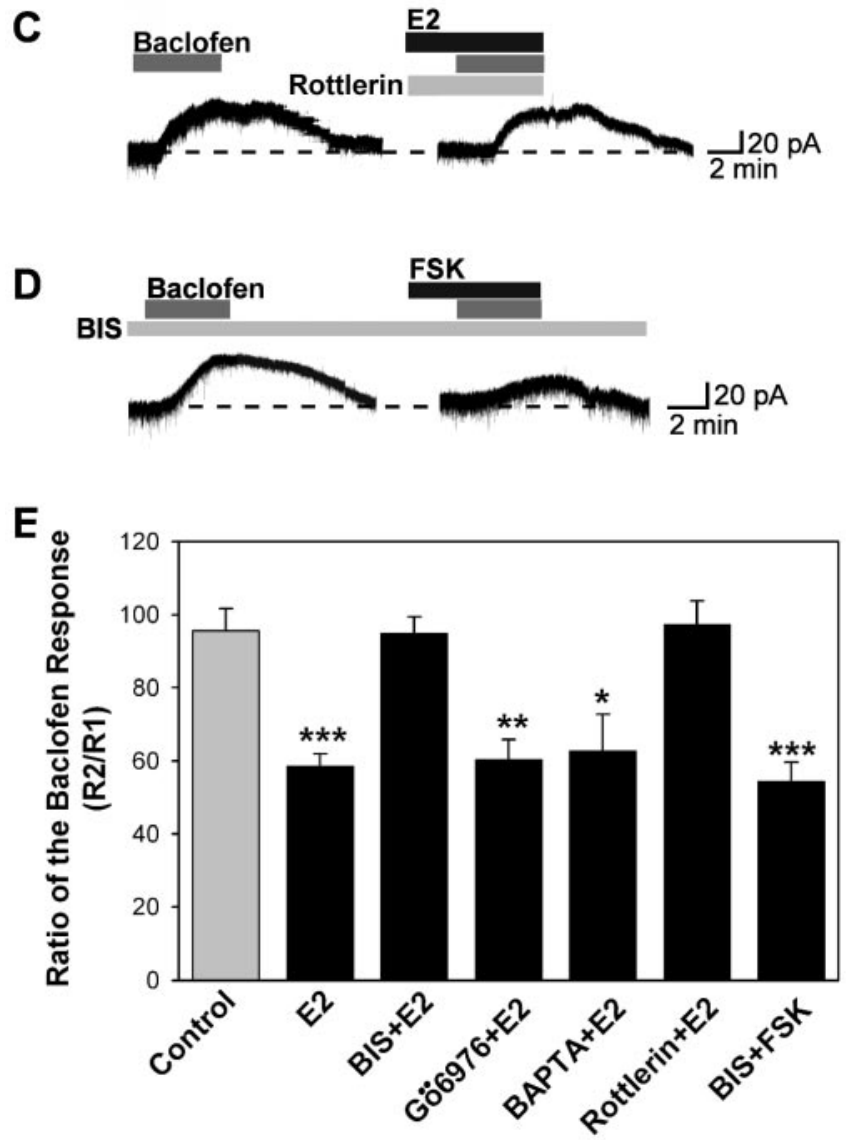

Figure 6. $E_{2}$ attenuation of the $G A B A_{B}$ response involves protein kinase $C \delta$. $A-D$, Representative traces of the baclofen responses in the presence of PKC inhibitors. Experiments were conducted as described in Figure 1. For the BIS or fast $\mathrm{Ca}^{2+}$ chelator BAPTA, cells were dialyzed for $15 \mathrm{~min}$ before baclofen application with BAPTA (replacing the $11 \mathrm{~mm}$ EGTA with $10 \mathrm{~mm}$ BAPTA) or BIS (100 nM), which were included in the patch pipette solution. E, Bar graph summarizing the effects of PKC inhibitors. The broad PKC inhibitor BIS and a selective PKC $\delta$ inhibitor rottlerin $(5 \mu \mathrm{M})$ could reverse, but the selective inhibitor of conventional PKC is oforms Gö6976 $(2 \mu \mathrm{M})$ or BAPTA could not block the attenuation of the baclofen response by $E_{2}$. BIS could not block the attenuation of the baclofen response by forskolin (FSK; $10 \mu \mathrm{M}$ ). Error bars represent the mean \pm SEM of $4-11$ cells tested per group. ${ }^{*} p<0.05,{ }^{* *} p<0.01$, and ${ }^{* * *} p<0.005$ versus vehicle control.

action of PKC is upstream of the activation of PKA. Therefore, we focused on pathways upstream of PKC to elucidate further the $\mathrm{E}_{2}$-mediated signaling pathway. To examine whether the estrogen receptor-mediated inhibition of the $\mathrm{GABA}_{\mathrm{B}}$ response depended on the activation of $\mathrm{G} \alpha$, arcuate neurons were dialyzed with a peptide (11 amino acids) that mimics the $\mathrm{C}$-terminal binding site of $\mathrm{G} \alpha_{\mathrm{q}}$ (Akhter et al., 1998). This peptide blocks the 


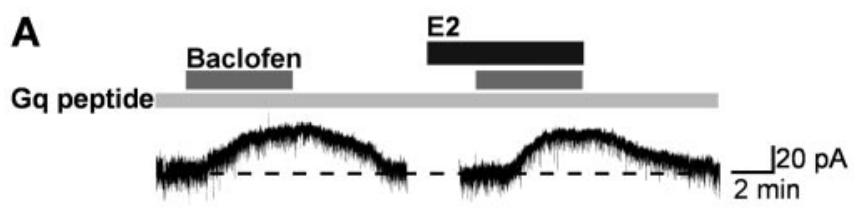

B

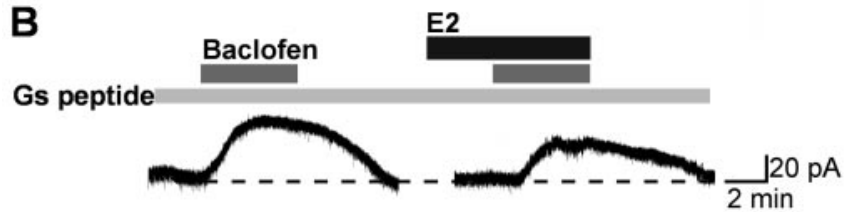

C

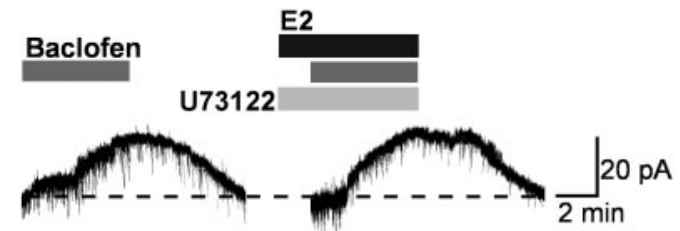

D

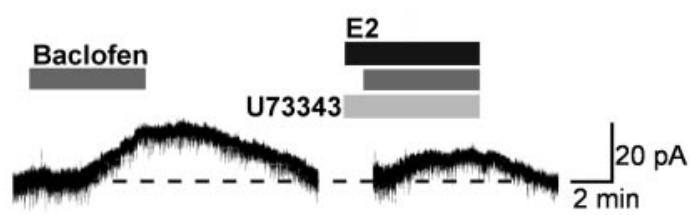

E

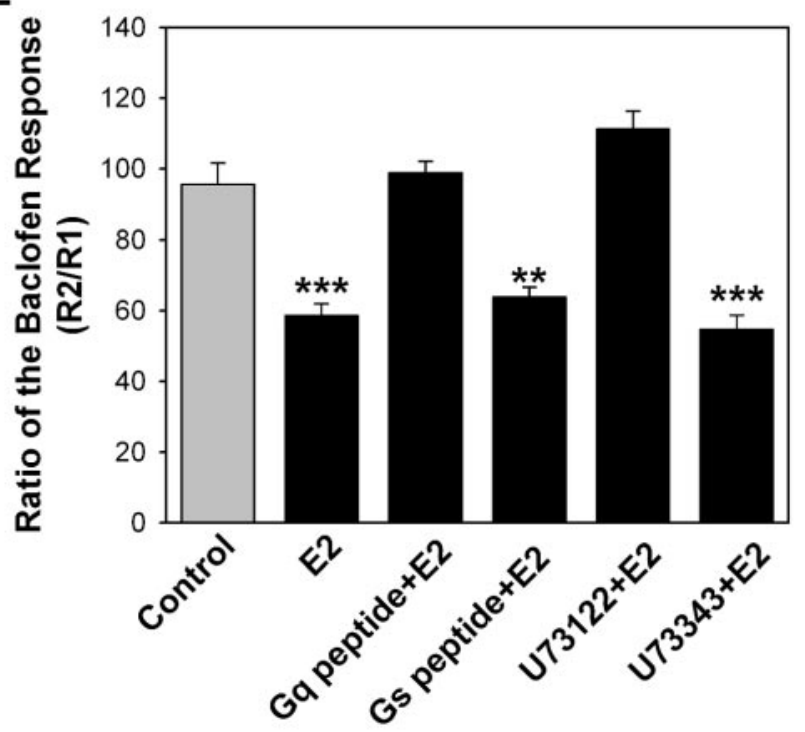

Figure 7. $E_{2}$ attenuation of the $G A B A_{B}$ response depends on activation of $G \alpha_{q}$, and PKC activation is in the upstream of PKA. $A-D$, Representative traces of the baclofen responses in the presence of PLC and $\mathrm{G} \alpha_{\mathrm{q}}$ inhibitors. Experiments were conducted as described in Figure 1. Cells were dialyzed for 15 min before baclofen application with $\mathrm{G} \alpha_{\mathrm{q}}(200 \mu \mathrm{M})$ or $\mathrm{G} \alpha_{\mathrm{s}}$ peptide (200 $\mu \mathrm{M})$. E, Bar graphs summarizing the effects of PLC and $\mathrm{G}_{\mathrm{q}}$ peptide. The PLC inhibitor U73122 (10 $\mu \mathrm{M})$ and $\mathrm{G} \alpha_{\mathrm{q}}$ peptide could inhibit, but the inactive analog of U73122, U73343 $(10 \mu \mathrm{M})$, and $G \alpha$ septide could not block the attenuation of the baclofen response by $E_{2}$. Error bars represent the mean \pm SEM of $4-11$ cells tested per group. ${ }^{* *} p<0.01$ and ${ }^{* * *} p<0.005$ versus vehicle control; $\mathrm{U} 73122$ plus $\mathrm{E}_{2}$ versus $U 73343$ plus $\mathrm{E}_{2}, p<0.05 ; \mathrm{G}_{\mathrm{q}}$ peptide plus $\mathrm{E}_{2}$ versus $\mathrm{G}_{\mathrm{s}}$ peptide plus $\mathrm{E}_{2}, p<0.05$.

interaction between G-protein-coupled receptors and $\mathrm{G} \alpha$ proteins. In cells dialyzed with this peptide $(200 \mu \mathrm{M})$, the $\mathrm{E}_{2}$ mediated reduction of the $\mathrm{GABA}_{\mathrm{B}}$ response was blocked significantly (Fig. $7 A, E$ ) compared with cells dialyzed with a control peptide (11 amino acids) that mimics the C-terminal domain of $\mathrm{G} \alpha_{\mathrm{s}}$ (Fig. $7 B, E$ ).

In light of these results for a primary role for $\mathrm{G} \alpha_{\mathrm{q}}$ in $\mathrm{E}_{2^{-}}$ mediated rapid inhibition, we tested whether the activation of PLC, a well known $\mathrm{G} \alpha_{\mathrm{q}}$ effector, might also play a role. To determine whether the activation of PLC $\beta$ is required for the estrogeninduced inhibition of $\mathrm{GABA}_{\mathrm{B}}$ response, neurons were treated with the broad-spectrum PLC inhibitor U73122 (10 $\mu \mathrm{M})$. U73122 $(10 \mu \mathrm{M})$ was perfused in the extracellular bathing media. Under these conditions, the estrogen-mediated reduction of $\mathrm{GABA}_{\mathrm{B}}$ response was blocked (Fig. 7C,E), whereas the less active PLC inhibitor U73343 at the same concentration had no effect (Fig. $7 D, E)$.

The attenuation of the $\mathrm{GABA}_{\mathrm{B}}$ response does not involve MAP kinase

Recent studies have shown that $17 \beta-\mathrm{E}_{2}$ rapidly activates the MAP kinase pathway in primary neuronal cortical cultures and in organotypic cerebrocortical explant cultures (Watters et al., 1997; Singh et al., 1999, 2000). We therefore tested whether inhibition of MAP kinase activity could prevent estrogen modulation of the baclofen response. Treatment with MAP kinase inhibitors PD98059 $(10 \mu \mathrm{M}$, in the pipette) or U0126 (5 $\mu \mathrm{M})$ did not affect $\mathrm{E}_{2}$ inhibition of baclofen responses (R2/R1 for $\mathrm{E}_{2}, 58.6 \pm 3.4 \%$, $n=10$; vs PD98059 plus $\left.\mathrm{E}_{2}, 66.1 \pm 11.8 \%, n=5\right)$.

Expression of $\mathrm{GABA}_{\mathrm{B}}$ receptor $\mathrm{PKC} \delta$ and adenylate cyclase VII transcripts in arcuate (GABA, dopamine, and POMC) neurons

Using single-cell RT-PCR from 75 acutely dispersed arcuate neurons, we found that $90 \%$ of the neurons expressed $\mathrm{GAD}_{65}$ transcripts, including TH-expressing and POMC-expressing neurons (data not shown). Most importantly, 92\% of the neurons expressed $\mathrm{GABA}_{\mathrm{B}}-\mathrm{R} 2$ transcripts, which correlates with the $90 \%$ response rate to baclofen. Furthermore, we also determined that dopamine and POMC neurons express PKC $\delta$ and adenylyl cyclase VII transcripts using single-cell RT-PCR. In one group of cells $(n=22)$, we found that PKC $\delta$ and adenylyl cyclase VII transcripts are expressed in the majority (70\%) of TH neurons (Fig. 8A), including those that coexpress $\mathrm{GAD}_{65}$. TH and GAD were colocalized in $60 \%$ of this population of neurons because of a limited amount of cDNA from individual neurons, POMC expression was determined in another group of cells $(n=29)$, and we found that PKC $\delta$ and adenylyl cyclase VII transcripts were expressed in the majority (75\%) of POMC neurons, including those that coexpress $\mathrm{GAD}_{65}$ (Fig. $8 \mathrm{~B}$ ). POMC and GAD were colocalized in $28 \%$ of this population of neurons. Therefore, the single-cell RT-PCR data support the electrophysiological findings that dopamine and POMC neurons express the critical transcripts for rapid estrogen signaling.

\section{Discussion}

A unique membrane estrogen receptor mediates the rapid effects of $\mathrm{E}_{2}$

Estrogen suppresses the action of the $\mathrm{GABA}_{\mathrm{B}}$ receptor agonist baclofen to activate GIRK channels in GABA, POMC, and dopamine neurons. This $\mathrm{E}_{2}$ effect is rapid, with measurable suppression occurring within minutes after addition of $\mathrm{E}_{2}$. The kinetics of this response support the notion that a membrane $\mathrm{E}_{2}$ receptor is mediating the response and argue against the involvement of the classical nuclear estrogen receptors operating by transcription regulation.

The pharmacology we observed for this rapid estrogen re- 

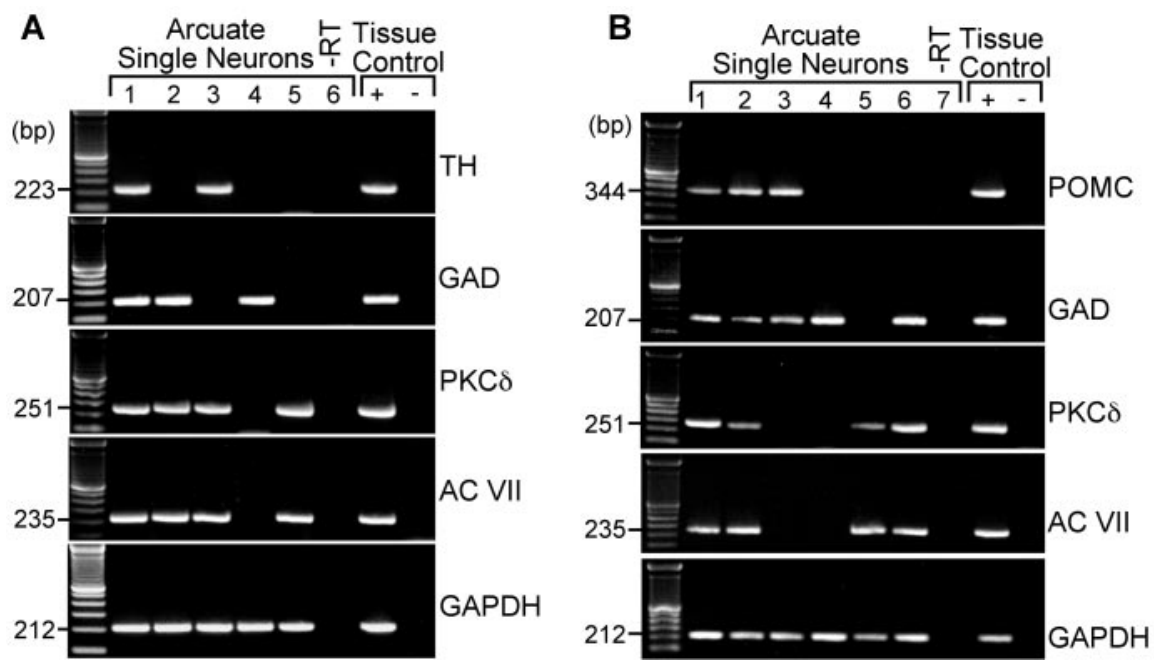

Figure 8. Expression of $\mathrm{GAD}, \mathrm{TH}, \mathrm{POMC}, \mathrm{PKC} \delta$, and $A C \mathrm{VII} \mathrm{mRNA}$ in arcuate neurons. Two representative gels illustrating that single arcuate neurons express mRNA for TH, GAD, PKC $\delta, A C V I I$, and GAPDH $(A)$ or mRNA for POMC, GAD, PKC $\delta, A C V I I$, and GAPDH (B). The expected size of the PCR products is as follows (in bp): GAD, 207; TH, 223; POMC, 344; PKC $\delta, 251$; AC VII, 235; and GAPDH, 212. GAPDH transcripts were analyzed in the same cells as an internal control for the RT reaction. One cell contained no RT as a negative control ( - RT). Basal hypothalamic tissue RNA was also reverse transcribed in the presence of RT (tissue controls, + ). A tissue control without RT (-) was included in each experiment. In addition, the following controls were included: HBSS from the dispersed cellular milieu and a water blank, both of which were negative after RT-PCR (data not shown).

sponse further supports the involvement of a novel transmembrane estrogen receptor. The membrane-impermeable $\mathrm{E}_{2}-\mathrm{BSA}$ conjugate gives an identical response to free $\mathrm{E}_{2}$, suggesting that the hormone-binding site of this receptor is accessible from the extracellular surface of the plasma membrane. The $\mathrm{E}_{2}$ response is stereospecific with respect to the configuration of the D-ring hydroxyl group; $17 \beta$-estradiol elicits the rapid response, whereas $17 \alpha$-estradiol is inactive. This is notable because $17 \alpha$-estradiol functions as an agonist of the nuclear ERs, albeit with slightly reduced potency compared with $17 \beta$-estradiol (Barkhem et al., 1998). The SERMs 4-OH tamoxifen, raloxifene, and GW-5638 all behave like $\mathrm{E}_{2}$ in mediating this response, whereas the steroidal anti-estrogen ICI 182,780 antagonizes the $\mathrm{E}_{2}$ response. Most importantly, the novel SERM STX that is devoid of estrogen (or anti-estrogen) activity with the nuclear ERs is a stronger activator of this rapid $\mathrm{E}_{2}$ response than $\mathrm{E}_{2}$, even at a 10 -fold lower concentration. Moreover, we know that this membrane ER has a subnanomolar affinity for estrogen on the basis of our pharmacological (Schild) analysis (Lagrange et al., 1997). These results demonstrate that the pharmacology of this rapid response is different and, in the case of STX, separable from that of the nuclear ERs (Razandi et al., 1999; Levin, 2001; Chambliss and Shaul, 2002).

Recently, Toran-Allerand et al. (2002) identified a highaffinity, saturable estrogen receptor, ERX, that is associated with caveolar-like microdomains in developing neocortical neurons. This membrane-associated receptor is coupled to the activation of MAPKs (MAP kinases), ERK1 (extracellular-signal related kinase 1), and ERK2, which appear to be important for the development and survival of neurons (Watters et al., 1997; Singh et al., 1999, 2000; Fitzpatrick et al., 2002). Interestingly, ERX also has a distinct pharmacology in that $17 \alpha$-estradiol is equipotent as $\mathrm{E}_{2}$ in activating the MAP kinase pathway (Wade et al., 2001; ToranAllerand et al., 2002). However, we did not see any effects of $17 \alpha$-estradiol on the $\mathrm{GABA}_{\mathrm{B}}$ response (present findings) or the $\mu$-opioid response, which is coupled to the same family of GIRK channels in hypothalamic neurons (Lagrange et al., 1997). Similarly, Gu and Moss (1996) found that $17 \alpha$-estradiol did not mimic the actions of $\mathrm{E}_{2}$ in the hippocampus to potentiate the glutamate (kainate)-mediated currents in CA1 pyramidal neurons. Likewise, Mermelstein et al. (1996) found that $17 \alpha$-estradiol was much less efficacious than $\mathrm{E}_{2}$ in reducing L-type calcium currents in neostriatal neurons. Therefore, it appears that the membrane estrogen receptor that modulates channel activity in neurons via the PKCPKA pathway is pharmacologically distinct from the receptor that is coupled to activation of ERK1 and ERK2 that promotes growth and survival.

Although the $\mathrm{GABA}_{\mathrm{A}}$ ionotropic receptor has been identified as a target for $5 \alpha$ reduced progesterone metabolites in CNS neurons (Harrison et al., 1987; Lambert et al., 1995; Rupprecht and Holsboer, 1999), the nature of the transmembrane receptor for estrogen that uncouples $\mathrm{GABA}_{\mathrm{B}}(\mu$ opioid) receptors from GIRK is not known. In sea trout oocytes, progestins inhibit adenylyl cyclase via a pertussis toxinsensitive mechanism to initiate oocyte maturation, and recently, a high-affinity progestin, GPCR, has been cloned from spotted seatrout oocytes (Zhu et al., 2003). However, whether there is an estrogen GPCR with similar homology needs to be determined.

\section{$\mathrm{E}_{2}$ activates PKC $\delta$ and PKA to alter the coupling of GPCRs to} $\mathrm{K}^{+}$channels in hypothalamic neurons

A number of studies have shown that protein kinase pathways affect $\mathrm{GABA}_{\mathrm{B}}$ receptor-mediated signaling in CNS neurons. Activation of protein kinase $C$ suppresses the $\mathrm{GABA}_{\mathrm{B}}$ receptor activation of GIRK channels in the hippocampal CA1 pyramidal neurons (Dutar and Nicoll, 1988) and attenuates the $\mathrm{GABA}_{\mathrm{B}}$ receptor-mediated inhibition of norepinephrine release from cerebellar slices (Taniyama et al., 1992).

Currently, there are 12 known members of the PKC family (Way et al., 2000). The family is divided into three groups on the basis of sequence homology and biochemical regulation. Class A, or conventional PKCs (PKC $\alpha, \beta \mathrm{I}, \beta \mathrm{II}$, and $\gamma$ ) are the well known, $\mathrm{Ca}^{2+}$-dependent PKCs. Class B, or novel PKCs $(\mathrm{PKC} \delta, \epsilon, \theta$, and $\eta)$, are $\mathrm{Ca}^{2+}$-independent. Finally, class $\mathrm{C}$ PKCs, or atypical PKCs (PKC $\zeta$ and $\tau / \lambda$ ), are the most divergent class. Atypical PKCs are also $\mathrm{Ca}^{2+}$ independent and do not require diacylglycerol for activation (Way et al., 2000). We found that the rapid $\mathrm{GABA}_{\mathrm{B}}$-suppressing effects of estrogen in hypothalamic neurons were sensitive to the broad-spectrum PKC inhibitor BIS but not to Gö6976, suggesting the involvement of a PKC not belonging to the conventional PKC class. In addition, the inhibition of estrogen of the $\mathrm{GABA}_{\mathrm{B}}$ response was not altered by inclusion of $10 \mathrm{~mm}$ BAPTA in the intracellular recording patch pipette, providing additional evidence that the $\mathrm{Ca}^{2+}$-dependent conventional PKCs are not involved. However, the selective PKC $\delta$ inhibitor rottlerin blocked the actions of $\mathrm{E}_{2}$, suggesting that this novel-class $\mathrm{PKC}$ is a mediator of the rapid $\mathrm{E}_{2}$ response. Moreover, our scRT-PCR data on the expression of $\mathrm{PKC} \delta$ transcripts in arcuate neurons support the involvement of $\mathrm{PKC} \delta$ in the $\mathrm{E}_{2}$-mediated inhibition of the $\mathrm{GABA}_{\mathrm{B}}$ response. Likewise, $\mathrm{PKC} \delta$ is involved in the estrogen- 
mediated inhibition of $\mathrm{K}^{+}$channels and fluid retention in female distal colonic epithelial cells, although the upstream signaling pathway is not known (Doolan et al., 2000).

\section{PKC activation is in the upstream of PKA activation}

In our study, internal perfusion of BIS could completely block the inhibition of the baclofen response by $\mathrm{E}_{2}$ but could not attenuate the inhibition of the baclofen response by forskolin applied via bath perfusion. PKC is known to activate adenylyl cyclases (Jacobowitz et al., 1993; Yoshimura and Cooper, 1993; Lin and Chen, 1998); moreover, when AC is activated by PKC instead of by $\mathrm{G} \alpha_{\mathrm{s}}$ or forskolin, it is resistant to inhibition by $\mathrm{G} \alpha_{\mathrm{i}}$ (Pieroni et al., 1993). To date, nine AC isozymes have been cloned (AC types I-IX). Notably, AC VII has a potential binding site for $\mathrm{PKC} \delta$ that is not present in the sequences of the other adenylyl cyclases, which would allow PKC $\delta$ to directly phosphorylate AC VII (Nelson et al., 2003). Interestingly, GABA neurons in the cortex, hippocampus, striatum, and cerebellum are immunoreactive for AC VII (Mons et al., 1998), and, in the present study, we show that hypothalamic GABA, TH, and POMC neurons express AC VII transcripts.

\section{$\mathrm{G} \boldsymbol{\alpha}_{\mathrm{q}}$ mediates the inhibition of the} $\mathrm{GABA}_{\mathrm{B}}$ response by $\mathrm{E}_{2}$ through PLC Most PKCs are activated by diacylglycerol, and some require the presence of $\mathrm{Ca}^{2+}$. Thus, PKCs are downstream of the PLCinositol triphosphate-diacylglycerol signaling cascade. Because different forms of PLC can be activated by various messengers, including $\mathrm{G} \alpha_{\mathrm{q}}, \mathrm{G} \beta \gamma(\mathrm{PLC} \beta)$, and tyrosine kinases (PLC $\gamma$ ), the $\mathrm{PKC}$ family is involved in a diverse array of signaling cascades (Tanaka and Nishizuka, 1994; Battaini, 2001). Our results show that a membrane ER is specifically coupled to $\mathrm{G} \alpha_{\mathrm{q}}$ protein. This conclusion is based on experiments in which intracellular dialysis with a peptide fragment of $\mathrm{G} \alpha_{\mathrm{q}}$ blocked the receptor interaction with $\mathrm{G}$-protein. This $\mathrm{G} \alpha_{\mathrm{q}}$ peptide has been used to block $\mathrm{G} \alpha_{\mathrm{q}}$ signaling pathways in cortical pyramidal neurons (Carr et al., 2002). In addition, the estrogen-mediated reduction of the $\mathrm{GABA}_{\mathrm{B}}$ response was significantly reduced by the phospholipase C inhibitor U73122 compared with cells perfused with the less active inhibitor U73343.

Therefore, from the collective results of this study, we formulate the signal transduction pathway for the rapid response to estrogen in hypothalamic neurons depicted in Figure 9. The sequence of events in this model are as follows: (1) $\mathrm{E}_{2}$ binds to a novel transmembrane estrogen receptor; (2) ligand binding activates $\mathrm{G} \alpha$; (3) activated $\mathrm{G} \alpha_{\mathrm{q}}$ in turn activates PLC; (4) activated PLC liberates DAG; (5) free DAG stimulates $\mathrm{PKC} \delta$; (6) $\mathrm{PKC} \delta$ activates adenylyl cyclase (VII); (7) cAMP levels are elevated; (8) cAMP stimulates PKA; and (9) PKA phosphorylates membrane targets critical for $\mathrm{K}^{+}$channel function.

\section{Functional significance of rapid membrane effects of $E_{2}$ in CNS neurons}

It was discovered previously that $\mathrm{E}_{2}$ could rapidly modulate synaptic efficacy via activation of PKA ( $\mathrm{Gu}$ and Moss, 1996, 1998; Lagrange et al., 1997; Kelly et al., 1999). Presently, we delineated the upstream components of this signaling pathway that includes $\mathrm{G}_{\mathrm{q}}$, phospholipase $\mathrm{C}$, and $\mathrm{PKC} \delta$ activation (Fig. 9). This is a novel signaling pathway for $\mathrm{E}_{2}$ to rapidly modulate hypothalamic neuronal excitability, and there is most likely a similar $\mathrm{E}_{2}$ signaling pathway in hippocampal CA1 neurons ( $\mathrm{Gu}$ and Moss, 1996, 1998). Therefore, we believe that this pathway is important for increasing synaptic efficacy not only in hypothalamic neurons but also in other neurons in the CNS. In addition, we identified a specific ligand (STX) that is selective for activating this pathway. The consequences of STX effects in hypothalamic neurons are evident in that these neurons are involved in controlling the ovulatory cycle, lactation, stress responses, temperature, and energy balance, all of which require rapid feedback regulation by estrogen. Furthermore, having a selective $\mathrm{E}_{2}$ agonist for rapid signaling is critical because SERMs such as tamoxifen and raloxifene increase the incidence of hot flashes in women, suggesting that they act as $\mathrm{E}_{2}$ antagonists in the hypothalamus (Stearns et al., 2002; Sherwin, 2003). In addition, raloxifene treatment is no better than placebo treatment in maintaining cognitive performance of postmenopausal women (Sherwin, 2003), which suggests that 
raloxifene is not an $\mathrm{E}_{2}$ agonist in hippocampus. Most importantly, raloxifene and tamoxifen bind to $\operatorname{ER} \alpha$ and $\operatorname{ER} \beta$ with high affinity (Barkhem et al., 1998). In contrast, the STX $\left(\mathrm{E}_{2}\right)$ receptor is similarly coupled as the serotonin $5 \mathrm{HT}_{2 \mathrm{~A}, \mathrm{C}}$ receptor (Carr et al., 2002) in CNS neurons, which may explain the ability of serotonin uptake inhibitors (SSRIs) to prevent hot flashes in postmenopausal women (Stearns et al., 2002). Hence, we would predict that STX would prevent hot flashes, maintain sleep cycles, elevate mood, etc. Therefore, this rapid PLC-PKC $\delta$-PKA signaling of $\mathrm{E}_{2}$ may synergize with CNS transmitter systems to enhance synaptic efficacy in brain circuits that are critical for maintaining homeostatic functions.

\section{References}

Akema T, Chiba A, Kimura F (1990) On the relationship between noradendritic stimulatory and GABAergic inhibitory systems in the control of luteinizing hormone secretion in female rats. Neuroendocrinology 52:566-572.

Akhter SA, Luttrell LM, Rockman HA, Iaccarino G, Lefkowitz RJ, Koch WJ (1998) Targeting the receptor-Gq interface to inhibit in vivo pressure overload myocardial hypertrophy. Science 280:574-577.

Barkhem T, Carlsson B, Nilsson Y, Enmark E, Gustafsson JÅ, Nilsson S (1998) Differential response of estrogen receptor $\alpha$ and estrogen receptor $\beta$ to partial estrogen agonists/antagonists. Mol Pharmacol $54: 105-112$.

Battaini F (2001) Protein kinase C isoforms as therapeutic targets in nervous system disease states. Pharmacol Res 44:353-361.

Björklund A, Lindvall O (1984) Dopamine-containing systems in the CNS. In: Handbook of chemical neuroanatomy: classical transmitters in the CNS, Pt 1 (Björklund A, Hökfelt T, eds), pp 55-122. Amsterdam: Elsevier.

Carr DB, Cooper DC, Ulrich SL, Spruston N, Surmeier DJ (2002) Serotonin receptor activation inhibits sodium current and dendritic excitability in prefrontal cortex via a protein kinase C-dependent mechanism. J Neurosci 22:6846-6855.

Chambliss KL, Shaul PW (2002) Estrogen modulation of endothelial nitric oxide synthase. Endocr Rev 23:665-686.

Dave JR, Rubinstein N, Eskay RL (1985) Evidence that $\beta$-endorphin binds to specific receptors in rat peripheral tissues and stimulates the adenylate cyclase-adenosine 3', 5'-monophosphate system. Endocrinology 117:1389-1396

Demotes-Mainard J, Arnauld E, Vincent JD (1990) Estrogens modulate the responsiveness of in vivo recorded striatal neurons to iontophoretic application of dopamine in rats: role of $\mathrm{D}_{1}$ and $\mathrm{D}_{2}$ receptor activation. J Neuroendocrinol 2:825-832.

Doolan CM, Condliffe SB, Harvey BJ (2000) Rapid non-genomic activation of cytosolic cyclic AMP-dependent protein kinase activity and $\left[\mathrm{Ca}^{2+}\right]_{\mathrm{i}}$ by 17 $\beta$-oestradiol in female rat distal colon. Br J Pharmacol 129:1375-1386.

Dutar P, Nicoll RA (1988) Pre- and postsynaptic GABA(B) receptors in the hippocampus have different pharmacological properties. Neuron $1: 585-591$.

Ferin M, Van Vugt D, Wardlaw S (1984) The hypothalamic control of the menstrual cycle and the role of endogenous opioid peptides. Recent Prog Horm Res 40:441-485.

Fitzpatrick JL, Mize AL, Wade CB, Harris JA, Shapiro RA, Dorsa DM (2002) Estrogen-mediated neuroprotection against $\beta$-amyloid toxicity requires expression of estrogen receptor $\alpha$ or $\beta$ and activation of the MAPK pathway. J Neurochem 82:674-682.

Gu Q, Moss RL (1996) 17 $\beta$-Estradiol potentiates kainate-induced currents via activation of the cAMP cascade. J Neurosci 16:3620-3629.

Gu Q, Moss RL (1998) Novel mechanism for non-genomic action of $17 \beta$ estradiol on kainate-induced currents in isolated rat CAl hippocampal neurones. J Physiol (Lond) 506:745-754.

Harrison NL, Majewska MD, Harrrington JW, Barker JL (1987) Structureactivity relationships for steroid interaction with the gammaaminobutyric $\operatorname{acid}_{\mathrm{A}}$ receptor complex. J Pharmacol Exp Ther 241:346-353.

Herbison AE (1997) Estrogen regulation of GABA transmission in rat preoptic area. Brain Res Bull 44:321-326.

Herbison AE, Horvath TL, Naftolin F, Leranth C (1995) Distribution of estrogen receptor-immunoreactive cells in monkey hypothalamus: rela- tionship to neurones containing luteinizing hormone-releasing hormone and tyrosine hydroxylase. Neuroendocrinology 61:1-10.

Herbison AE, Skynner MJ, Sim JA (2001) Lack of detection of estrogen receptor- $\alpha$ transcripts in mouse gonadotropin-releasing hormone neurons. Endocrinology [Erratum] 142:492-493.

Hökfelt T, Mårtensson R, Björklund A, Kleinau S, Goldstein M (1984) Distributional maps of tyrosine-hydroxylase-immunoreactive neurons in the rat brain. In: Handbook of chemical neuroanatomy (Björklund A, Hökfelt T, eds), pp 277-379. Amsterdam: Elsevier.

Jacobowitz O, Chen J, Premont RT, Iyengar R (1993) Stimulation of specific types of Gs-stimulated adenylyl cyclases by phorbol ester treatment. J Biol Chem 268:3829-3832.

Jarry H, Leonhardt S, Wuttke W (1995) The inhibitory effect of $\beta$-endorphin on LH release in ovariectomized rats does not involve the preoptic GABAergic system. Exp Clin Endocrinol Diabetes 103:317-323.

Katzenellenbogen JA, Carlson KE, Katzenellenbogen BS (1985) Facile geometric isomerization of phenolic non-steroidal estrogens and antiestrogens: limitations to the interpretation of experiments characterizing the activity of individual isomers. J Steroid Biochem 22:589-596.

Kelly MJ, Wagner EJ (1999) Estrogen modulation of G-protein-coupled receptors. Trends Endocrinol Metab 10:369-374.

Kelly MJ, Rønnekleiv OK (1994) Electrophysiological analysis of neuroendocrine neuronal activity in hypothalamic slices. In: Methods in neurosciences: pulsatility in neuroendocrine systems (Levine JE, ed), pp 47-67. San Diego: Academic.

Kelly MJ, Rønnekleiv OK, Eskay RL (1984) Identification of estrogenresponsive LHRH neurons in the guinea pig hypothalamus. Brain Res Bull 12:399-407.

Kelly MJ, Loose MD, Rønnekleiv OK (1990) Opioids hyperpolarize $\beta$-endorphin neurons via mu-receptor activation of a potassium conductance. Neuroendocrinology 52:268-275.

Kelly MJ, Loose MD, Rønnekleiv OK (1992) Estrogen suppresses $\mu$-opioid and $\mathrm{GABA}_{\mathrm{B}}$-mediated hyperpolarization of hypothalamic arcuate neurons. J Neurosci 12:2745-2750.

Kelly MJ, Lagrange AH, Wagner EJ, Rønnekleiv OK (1999) Rapid effects of estrogen to modulate G-protein-coupled receptors via activation of protein kinase A and protein kinase C pathways. Steroids 64:64-75.

Lagrange AH, Rønnekleiv OK, Kelly MJ (1994) The potency of $\mu$-opioid hyperpolarization of hypothalamic arcuate neurons is rapidly attenuated by $17 \beta$-estradiol. J Neurosci 14:6196-6204.

Lagrange AH, Rønnekleiv OK, Kelly MJ (1995) Estradiol-17 $\beta$ and muopioid peptides rapidly hyperpolarize GnRH neurons: a cellular mechanism of negative feedback? Endocrinology 136:2341-2344.

Lagrange AH, Wagner EJ, Rønnekleiv OK, Kelly MJ (1996) Estrogen rapidly attenuates a $\mathrm{GABA}_{\mathrm{B}}$ response in hypothalamic neurons. Neuroendocrinology 64:114-123.

Lagrange AH, Rønnekleiv OK, Kelly MJ (1997) Modulation of G-proteincoupled receptors by an estrogen receptor that activates protein kinase A. Mol Pharmacol 51:605-612.

Lambert JJ, Belelli D, Hill-Venning C, Peters JA (1995) Neurosteroids and $\mathrm{GABA}_{\mathrm{A}}$ receptor function. Trends Pharmacol Sci 16:295-303.

Leranth C, MacLusky NJ, Brown TJ, Chen EC, Redmond Jr DE, Naftolin F (1992) Transmitter content and afferent connections of estrogensensitive progestin receptor-containing neurons in the primate hypothalamus. Neuroendocrinology 55:667-682.

Levin ER (2001) Cell localization, physiology, and nongenomic actions of estrogen receptors. J Appl Physiol 91:1860-1867.

Lin W-W, Chen BC (1998) Distinct PKC isoforms mediate the activation of cPLA2 and adenylyl cyclase by phorbol ester in RAW264.7 macrophages. Br J Pharmacol 125:1601-1609.

Loose MD, Rønnekleiv OK, Kelly MJ (1990) Membrane properties and response to opioids of identified dopamine neurons in the guinea pig hypothalamus. J Neurosci 10:3627-3634.

Loose MD, Rønnekleiv OK, Kelly MJ (1991) Neurons in the rat arcuate nucleus are hyperpolarized by $\mathrm{GABA}_{\mathrm{B}}$ and mu-opioid receptor agonists: evidence for convergence at a ligand-gated potassium conductance. Neuroendocrinology 54:537-544.

Martiny-Baron G, Kazanietz MG, Mischak H, Blumberg PM, Kochs G, Hug H, Marme D, Schachtele C (1993) Selective inhibition of protein kinase C isozymes by the indolocarbazole Gö6976. J Biol Chem 268:9194-9197.

McEwen BS (2001) Estrogens effects on the brain: multiple sites and molecular mechanisms. J Appl Physiol 91:2785-2801. 
Mermelstein PG, Becker JB, Surmeier DJ (1996) Estradiol reduces calcium currents in rat neostriatal neurons via a membrane receptor. J Neurosci 16:595-604.

Mitsushima D, Marzban F, Luchansky LL, Burich AJ, Keen KL, Durning M, Golos TG, Terasawa E (1996) Role of glutamic acid decarboxylase in the prepubertal inhibition of the luteinizing hormone releasing hormone release in female rhesus monkeys. J Neurosci 16:2563-2573.

Mons N, Yoshimura M, Ikeda H, Hoffman PL, Tabakoff B (1998) Immunological assessment of the distribution of type VII adenylyl cyclase in brain. Brain Res 788:251-261.

Morrell JI, McGinty JF, Pfaff DW (1985) A subset of $\beta$-endorphin or dynorphin-containing neurons in the medial basal hypothalamus accumulates estradiol. Neuroendocrinology 41:417-426.

Neill JD (1980) Neuroendocrine regulation of prolactin secretion. Front Neuroendocrinol 6:129-155.

Nelson EJ, Hellevuo K, Yoshimura M, Tabakoff B (2003) Ethanol-induced phosphorylation and potentiation of the activity of type 7 adenylyl cyclase: involvement of PKC delta. J Biol Chem 278:4552-4560.

Paradiso K, Zhang J, Steinbach JH (2001) The C terminus of the human nicotinic $\alpha 4 \beta 2$ receptor forms a binding site required for potentiation by an estrogenic steroid. J Neurosci 21:6561-6568.

Pieroni JP, Jacobowitz O, Chen J, Iyengar R (1993) Signal recognition and integration by Gs-stimulated adenylyl cyclases. Curr Opin Neurobiol 3:345-351.

Razandi M, Pedram A, Greene GL, Levin ER (1999) Cell membrane and nuclear estrogen receptors (ERs) originate from a single transcript: studies of $\operatorname{ER} \alpha$ and ER $\beta$ expressed in Chinese hamster ovary cells. Mol Endocrinol 13:307-319.

Rupprecht R, Holsboer F (1999) Neuroactive steroids: mechanisms of action and neuropsychopharmacological perspectives. Trends Neurosci 22:410-416.

Seltzer AM, Donoso AO (1992) Restraining action of GABA on estradiolinduced LH surge in the rat: GABA activity in brain nuclei and effects of GABA mimetics in the medial preoptic nucleus. Neuroendocrinology $55: 28-34$.

Sherwin BB (2003) Estrogen and cognitive functioning in women. Endocr Rev 24:133-151.

Simonian SX, Spratt DP, Herbison AE (1999) Identification and characterization of estrogen receptor $\alpha$-containing neurons projecting to the vicinity of the gonadotropin-releasing hormone perikarya in the rostral preoptic area of the rat. J Comp Neurol 411:346-358.

Singh M, Setalo Jr G, Guan X, Warren M, Toran-Allerand CD (1999) Estrogen-induced activation of mitogen-activated protein kinase in cerebral cortical explants: convergence of estrogen and neurotrophin signaling pathways. J Neurosci 19:1179-1188.

Singh M, Setalo GJ, Guan X, Frail DE, Toran-Allerand CD (2000) Estrogeninduced activation of the mitogen-activated protein kinase cascade in the cerebral cortex of estrogen receptor- $\alpha$ knock-out mice. J Neurosci 20:1694-1700.

Stearns V, Ullmer L, Lopez JF, Smith Y, Isaacs C, Hayes D (2002) Hot flushes. Lancet 360:1851-1861.

Sullivan KA, Witkin JW, Ferin M, Silverman AJ (1995) Gonadotropinreleasing hormone neurons in the rhesus macaque are not immunoreactive for the estrogen receptor. Brain Res 685:198-200.

Takano K, Asano S, Yamashita N (1994) Activation of G-protein-coupled
$\mathrm{K}^{+}$channels by dopamine in human GH-producing cells. Am J Physio 266:E318-E325.

Tanaka C, Nishizuka Y (1994) The protein kinase C family for neuronal signaling. Annu Rev Neurosci 17:551-567.

Taniyama K, Niwa M, Kataoka Y, Yamashita K (1992) Activation of protein kinase $\mathrm{C}$ suppresses the gamma-aminobutyric acid B receptor-mediated inhibition of the vesicular release of noradrenaline and acetylcholine. J Neurochem 58:1239-1245.

Toran-Allerand CD, Guan X, MacLusky NJ, Horvath TL, Diano S, Singh M, Connolly Jr ES, Nethrapalli IS, Tinnikov AA (2002) ER-X: a novel, plasma membrane-associated, putative estrogen receptor that is regulated during development and after ischemic brain injury. J Neurosci 22:8391-8401.

Valverde MA, Rojas P, Amigo J, Cosmelli D, Orio P, Bahamonde MI, Mann GE, Vergara C, Latorre R (1999) Acute activation of Maxi-K channels (hSlo) by estradiol binding to the $\beta$ subunit. Science 285:1929-1931.

Wade CB, Robinson S, Shapiro RA, Dorsa DM (2001) Estrogen receptor (ER)alpha and ERbeta exhibit unique pharmacologic properties when coupled to activation of the mitogen-activated protein kinase pathway. Endocrinology 142:2336-2342.

Wagner EJ, Manzanares J, Moore KE, Lookingland KJ (1994) Neurochemical evidence that estrogen-induced suppression of kappa-opioidreceptor-mediated regulation of tuberoinfundibular dopaminergic neurons is prolactin-independent. Neuroendocrinology 59:197-201.

Wagner EJ, Bosch MA, Kelly MJ, Rønnekleiv OK (1999) A powerful GABA receptor-mediated inhibition of GABAergic neurons in the arcuate nucleus. NeuroReport 10:2681-2687.

Wagner EJ, Reyes-Vazquez C, Rønnekleiv OK, Kelly MJ (2000) The role of intrinsic and agonist-activated conductances in determining the firing patterns of preoptic area neurons in the guinea pig. Brain Res 879:29-41.

Wagner EJ, Rønnekleiv OK, Bosch MA, Kelly MJ (2001) Estrogen biphasically modifies hypothalamic GABAergic function concomitantly with negative and positive control of luteinizing hormone release. J Neurosci 21:2085-2093.

Watson RE, Langub MC, Landis JW (1992) Further evidence that most luteinizing hormone-releasing hormone neurons are not directly estrogenresponsive: simultaneous localization of luteinizing hormone-releasing hormone and estrogen receptor immunoreactivity in the guinea-pig brain. J Neuroendocrinol 4:311-317.

Watters JJ, Campbell JS, Cunningham MJ, Krebs EG, Dorsa DM (1997) Rapid membrane effects of steroids in neuroblastoma cells: effects of estrogen on mitogen-activated protein kinase signaling cascade and c-fos immediate early gene transcription. Endocrinology 138:4030-4033.

Way KJ, Chou E, King GL (2000) Identification of PKC-isoform-specific biological actions using pharmacological approaches. Trends Pharmacol Sci 21:181-187.

Wetzel CH, Hermann B, Behl C, Pestel E, Rammes G, Zieglgansberger W, Holsboer F, Rupprecht R (1998) Functional antagonism of gonadal steroids at the 5-hydroxytryptamine type 3 receptor. Mol Endocrinol 12:1441-1451.

Yoshimura M, Cooper DM (1993) Type-specific stimulation of adenylyl cyclase by protein kinase C. J Biol Chem 268:4604-4607.

Zhu Y, Rice CD, Pang Y, Pace M, Thomas P (2003) Cloning, expression, and characterization of a membrane progestin receptor and evidence it is an intermediary in meiotic maturation of fish oocytes. Proc Natl Acad Sci USA 100:2231-2236. 